\title{
Meta-parody in Contemporary Russian Media: Viewpoint Blending behind Dmitry Bykov's 2009 poem "Infectious"
}

\author{
Anna Pleshakova
}

Pleshakova, A. Meta-parody in contemporary Russian media: viewpoint blending behind Dmitry Bykov's 2009 poem "Infectious" // Lege artis. Language yesterday, today, tomorrow. The Journal of University of SS Cyril and Methodius in Trnava. Warsaw: De Gruyter Open, 2013, vol. 1 (1), June 2016. - p. 202-274. DOI: 10.1515/lart-2016-0005 ISSN 2453-8035

\begin{abstract}
The author uses the case of Dmitry Bykov's "Заразное" (Infectious) to explore metaparody, a genre, which has received very little attention in literary studies and has not been explored from the cognitive poetic perspective so far. The author investigates Bykov's performance of metaparody as a new Russian hybrid genre event, related to the new Russian ideology of nationalism, as well as the respective Kremlin-sponsored media discourse.
\end{abstract}

Keywords: cognitive poetics, conceptual blending, blended joint attention, viewpoint blending, (de-) compression, genre, meta-parody, parody, irony, deixis, cultural frames, metaphor, counterfactuality, multimodality, intertextuality, poetic blends, expository questions, Russian national identity, critical discourse analysis.

\section{Introduction}

The restoration of Russia as a great power was identified by Putin as a key goal upon his rise to supreme power in 1999. It was to be achieved, among other things, through the articulation and dissemination of a particular discourse of nation-building.

Tolz (Tolz /forthcoming/) argues that Putin's approach to the construction of Russian national identity has been "in some aspects, novel and, in others, determined by the legacy of the Soviet policies and the developments of the 1990s". She shows that the novel elements in Putin's approach have been very strong. Among them is the fact that despite Putin's policies of controlling the media and silencing the opposition, discourses of identity, overtly critical of the one emanating from the Kremlin, could be articulated publicly" (Tolz /forthcoming/). 
In the following sections of my article, I will zoom into contemporary Russian critical media discourse of nation-building in an attempt to reveal the complexity of viewpoint construction behind this type of discourse. I will focus on the poem of "Заразное" (Infectious), one example representing the critical discourse of Russian national identity formation, written by the prominent Russian writer and poet Dmitry Bykov. ${ }^{\mathrm{i}}$ This article written in verse was published in the Russian liberal newspaper 'Novaya Gazeta $^{\prime i i}$ in July 2009 in response to an official recommendation given by the Russian Chief Sanitary Inspector Onishchenko to Russian citizens, whereby he told them not to go to the UK because of the swine-flu epidemic. "Infectious" is especially interesting because it presents an example of a mixed or hybrid genre, reflecting a situation where "the frontiers between high and low culture are becoming blurred" - a new phenomenon for Russia (Marsh 2007: 99). This text is both a newspaper article and a literary text written in verse. I argue that it is also an example of meta-parody genre (a term coined by Morson 1989) - a rather challenging object for viewpoint construction analysis. Morson defines meta-parody as (Morson, 1989: 83):

As opposed to parody - double-voiced text, which clearly indicates which of their conflicting voices is to be regarded as authoritative, metaparody is a class of texts that are designed in such a way that readers do not know with which arguments of a target or a parody they are expected to agree. Thus, metaparody is a dialogical relation, an ultimately inconclusive dialogue.

The world-leading expert on parody Linda Hutcheon (2000) notes that researchers have found it difficult to define such very close concepts as parody, irony and satire and more often than not the respective terms have been used interchangeably. Adopting Hutcheon's (2000) definition of irony as a parody's rhetorical miniature, and drawing upon Tobin and Israel's (2012) study of irony as a viewpoint effect, I analyse metaparody as a type of viewpoint blending network observed at a larger rhetorical and discourse level. I focus on the following research questions: 1) what specifically in the viewpoint construction behind Bykov's "Infectious" makes the reader regard one of the voices (viewpoints) as more or less, or equally, authoritative; 2 ) are there certain types of linguistic viewpoint markers that trigger or constrain meta-parodic viewpoint blending network construction; 3) Does meta-parodic viewpoint blending network 
construction differ from parodic and ironic networks? If so, how? 4) What does the analysis of Bykov's meta-parody as a viewpoint blend tell us about critical media and literary discourses in Russia, as well as about the productivity of blended joint attention as an analytical tool?

In order to answer these questions, I approach the exploration of meta-parody genre from the interdisciplinary - cognitive poetic - perspective and analyse meta-parody as a communicative and discourse event, while employing blended joint attention, conceptual blending, viewpoint blending and linguistic viewpoint as the core analytical tools.

\section{Research framework: cognitive poetics, conceptual blending, and genre}

Cognitive poetics is a linguistic strand of cognitive approaches to literature, which draws upon cognitive linguistics and "deploys ideas from Stylistics and Discourse Analysis synthesised with new concepts from Cognitive Science" (Harbus, 2012: 6). Specifically, as Stockwell rightly points out, cognitive poetics afford consideration of the socio-political and cultural matters relevant to the analysis of the literary discourse in question, and interweaving the elements of both stylistics and critical discourse analyses. He argues that cognitive poetics "offers a genuine possibility of integrating the individual and the social in a principled way" (Stockwell 2007: 9). One example of such integration is Steen's (2011) framework for the exploration of genre, rooted in cognitive psychology and linking the humanities, the cognitive and social sciences through the 'language-cognition-communication' interface. Following Steen's framework aiming "to model what language users in fact do in terms of discourse processing" (Steen 2011: 30), I shall approach my cognitive poetic investigation of "Infectious" from the interdisciplinary perspective, utilizing conceptual blending as the research framework.

Conceptual integration or blending (CIB) is viewed as a general principle underlying the meaning construction in a range of both more and less complex mental phenomena. 
Within the research framework of CIB, networks are constructed to provide understanding of meanings. CIB networks consist of interconnected mental spaces partial representations connected to long-term schemes of knowledge called 'frames'. In a network there are two or more input spaces, one or more generic spaces that contain what the inputs have in common, and one or more blended spaces that are products of imaginative thinking and that contain some selected structure and elements from each of the inputs. All-important conceptual mappings - "vital relations" - between and within mental spaces may include: change, identity, time, space, cause-effect, part-whole, representation, role, analogy, disanalogy, property, similarity, category, intentionality, and uniqueness. In the blend, emergent structure (meaning, story, category, etc.) is developed through the processes of conceptual integration. These involve processes of composition, completion, and elaboration, as well as mappings, multidirectional projections, compression and blending. The networks are controlled by a number of constitutive and governing principles, as well as overarching goals. Constitutive principles - partial cross-space mappings, selective projection to the blend, and development of emergent structure in the blend - place strong constraints on running the conceptual network, and governing principles (compression, topology, pattern completion, integration, maximization of vital relations, intensification, web, unpacking, relevance) apply further constraints through the provision of strategies for optimising the network's emergent structure (see Fauconnier \& Turner 2002: Ch.16). Constitutive and governing principles cooperate in the following way: "Compression helps human scale, human scale helps getting a story, getting a story helps global insight, and going from Many to One helps the blend achieve human scale" (Fauconnier \& Turner, 2002: 336).

One of the major strengths of CIB theory is that it offers a systematic set of precise tools for analysis, which at the same time remains open in a sense that it can be developed further or combined with other tools, while maintaining the main logic of CIB. A number of researchers have utilised CIB whilst integrating it with other theories 
and methods, and have proved it to be a productive framework for interdisciplinary research. CIB has proved to be useful for the analysis of communication in literary and non-literary discourse (e.g., Brandt 2013; Pascual 2014); media and political discourse (e.g., Hart 2010; Pleshakova /forthcoming/); mixed literary genres' analysis (Sinding 2005 and 2010); metaphor analysis (e.g., Chilton 2005; Oakley \& Coulson 2008; Hart 2010); the analysis of multimodality (e.g., Forceville 2013; Sambre 2013). CIB provides an approach to discourse analysis which is socio-culturally committed (Hougaard \& Oakley 2008). CIB is viewed as a literary and a poetic technique (e.g., Brandt 2013; Dancygier 2006 iii; 2008; Freeman 2005; Lakoff \& Turner 1989; Pagan Canovas 2011; Semino 2006; Sweetser 2006) and as "the most important concept to cross over from Cognitive Science to Literary Studies, both because of its capacity to explain central, complex issues, and also its broad applicability" (Harbus, 2012: 52). The recent exploration of linguistic and multimodal viewpoint construction in both literary and non-literary discourses has drawn upon both mental spaces and conceptual blending theories (Dancygier \& Sweetzer 2012). Furthermore, the CIB has been enriched by the development of 'blended joint attention', a model accounting for analysis of viewpoint construction and viewpoint displacement in multimodal media discourse (Blended classic joint attention, s.a.; Nesset et al. 2014; Turner 2014). Since the exploration of meta-parodic "Infectious" as a complex genre event (a term offered by Steen 2011: 34) as well as a communicative event and media and literary discourse event, involves the examination of a rather complex viewpoint arrangement behind it, I employ CIB as the framework well-equipped to cope with the arising challenges of such an examination.

\section{Genre event of Infectious}

\subsection{The media story of Infectious: overview}

At first glance the story of "Infectious" (see Appendix 1) may be perceived as entertaining and satirical, but not particularly remarkable. In the first-person narrative of "Infectious", the post-Soviet Russian Speaker supports Onishchenko's 
recommendation 'not to travel to Britain', and then tells his own story of going to Britain (the OTHER Space), getting infected with the ideas of democracy and freedom, and then coming back to Russia (the SELF Space). Although at first feeling pretty strange, uncomfortable and ill in the undemocratic space of Russia, he soon recovers from the "democratic disease", and continues living there happily. In his "recovery" process, the Speaker asks questions, which are critical of Russia as an undemocratic space and answers them referring to the arguments core to the contemporary Kremlinsponsored Russian media discourse.

\subsubsection{Readers' perception}

Having read "Infectious" for the first time, I found it to be parodic and ironic but at the same time highly ambiguous. In order to check whether my intuitive perception of the text was shared by Russians living in Russia, in August 2009 I conducted a survey, in which I asked citizens residing in central Russia: 23 students aged 18-20 and 18 professionals aged 40-62, to read through "Infectious" and to answer the following question: "What emotions/impressions did you experience/have after reading this text?" The most frequent answers were: conflicted emotions; ambiguous impression; mixed feelings; a storm of emotions; negative emotions; the situation is not true, we too have something positive here; (in the speech marks, i.e. ironic) - "they [the abroad] will help us"; we need to look for the reasons of our problems, rather than to search for those whose fault it is; it is nobody's fault, it is everybody's fault; it is painful to see Russia in such a state; pride for my country; joy and pain/bitterness. Since emotion is viewed as key to media message understanding by the contemporary media psychology scholars, these answers have motivated me to take a closer look at "Infectious".

\section{2 "Infectious": irony, parody, or meta-parody?}

\subsubsection{Target of parody}

Hutcheon (2000) defines parody "as a form of repetition with ironic critical distance, marking difference rather than similarity" (Hutcheon 2000: xii). Indeed, we can label 207 
Bykov's "Infectious" as a parody since it repeats the arguments of the Kremlinsponsored media discourse through the utterances of the imagined Speaker, who is barely literate and not very intelligent. Bykov uses this Speaker, a typical representative of the Russian media audience, as a prism to conceptualise the SELF (Russia) space in its relation to the OTHER (Abroad) space, while adopting a number of techniques for creating irony. Bykov mocks the audience's oversimplified reception of Kremlin-sponsored media discourse, thereby choosing the Russian media audience as the main target of his parody. As noted by Morson (Morson 1989: 71):

Parodies are usually described and identified as being of (or "after") a particular author or work, but the parodist's principal target may, in fact, be a particular audience or class of readers. The etiology of utterance [parody] includes the pathology of reception.

Indeed, the Russian media audience constitutes the principle target of Bykov's parody, whereas the actual Kremlin-sponsored media discourse arguments related to Russian identity construction form the secondary (indirect) target of parody.

\subsubsection{Voices of parody and meta-parody}

Any parody is a double-voiced text/discourse (Hutcheon 2000: xiv; Morson 1989), since "it points to the differential but mutual dependence of parody and parodied texts". Central to the voices' joint work is "encoded intention, as inferred by the receiver as decoder" (Hutcheon 2000: 24). As Hutcheon further explains (2000: xiv):

When we speak of parody, we [...] imply an intention to parody another work (or set of conventions) and both a recognition of that intent and an ability to find and interpret the backgrounded text in its relation to the parody.

Morson (1989) uses the notion of 'intention' as one of three key criteria in his definition of parody: 1) evoke "the original utterance" - target of parody; 2) the former must be antithetical to its target; and 3) "the fact that it [parody] is intended by its author to have higher semantic authority than the original must be clear" (Morson 1989: 67). If the third criterion is not satisfied, the reader deals with a case of meta-parody rather than parody - "that is when readers do not know with which utterance they are expected to agree, or suspect that the second utterance [original] may be no more authoritative then the first [...]" (Morson 1989: 68). As shown above, "Infectious" 
satisfies the first two criteria. In order to establish whether the third criterion is satisfied we need to determine the nature of relation between the Author and the Reader in conceptualising the respective communicative intention of Bykov's "Infectious", as well as the ways in which this conceptualisation can be further examined.

\section{Exploring "Infectious" as a communicative event}

\subsection{Understanding of parodic communicative intention}

Indeed, "speakers can and do produce utterances that make their communicative intentions recognizable" (Sanders et al. 2013: 27). The results of experiments conducted by Sanders et al. (2013) to elucidate the calculability of communicative intentions through pragmatic reasoning, allowed them to view "conceptualisation of communicative intention as arising from discursive and social knowledge shared within a community about discursive means to ends, not a private cognitive state" and therefore "regard speakers and hearers as having a common basis for pragmatic reasoning that reliably links utterances in context with communicative intentions". Crucially, they regard speakers and third party "readers" as routinely engaged in such reasoning (Sanders et al. 2013: 27). Sanders et al. do not see a speaker's communicative intention as a property of the Speaker; they argue (Sanders et al. 2013: 4):

Rather, we have to regard a speaker's communicative intention as a property of the utterance (comprising its lexicon, syntax, and prosody) together with its discursive and social context, including the utterance's sequential placement within the discourse or task or activity at hand, its physical setting, and its interpersonal, institutional and cultural settings.

While looking into discourse events as communicative (enunciative) events, Brandt (2013) points out to the difference in constructing non-literary and literary text/discourse. She argues that for literary texts production and reception, things are represented in a mode of non-actuality, and representations set up in a semiotic base space are peculiarly free of situational constraints. She explains (Brandt 2013: 429):

Focus is on the what and the how of communication rather than the pragmatic particulars of who, where and when. These representations - the (semantic) what and the (presentational) how - are presented in an enunciatory mode of pretense, establishing an imagined semantic universe not identifiable with the pragmatic reality that normally motivates communication. Only through the 
(secondary and optional) abstraction process of literary interpretation do the authorial enunciation and the represented content become expressly related to the world outside the text.

Indeed, being a literary text, "Infectious" forces us to approach the interpretation of its communicative intention with the focus on the what and the how; at the same time being a media text and a parody, "Infectious" makes us equally consider who, where and when, both in terms of situational and contextual constraints. Hutcheon underscores that "as readers or viewers or listeners who decode parodic structures, we also act as decoders of encoded intent" (Hutcheon 2000: 23). She argues that parody involves the entire enunciation of discourse: "this enunciative act includes an addresser of the utterance, a receiver of it, a time and a place, discourses that precede and follow - in short, an entire context" (Hutcheon 2000: 23). Hutcheon insists on the importance of considering the parodic text's entire "situation in the world", including the time and the place, the ideological frame of reference, the personal as well as social context - not only of the instigator of the parody but also of its receiver (Hutcheon 2000: xiii). She views the process of communication as central to the understanding of parody and refers to it "as the enunciation or the contextualized production and reception of parodic texts" (Hutcheon 2000: xiii).

\subsection{Human communication and joint attention: Blended joint attention, the Ground, and} Viewpoint as an intersubjective phenomenon

Turner (2014; Blended classic joint attention, s.a.) rightly points out that joint attention is central for events of human communication. He underscores that any sophisticated human communication involves the blending web for joint attention, since in the process all participants would engage in creating a blended understanding of each other as fully minded. Furthermore, Turner (2014) argues that communicative events, which do not occur in face-to-face communication, tend to be even more complex events of blended joint attention often involving a scene of blended joint attention with cascades of nested blended selves and blended others (Turner 2014: 97-105). Central to this construction is the "ground" - one of the most basic mental frames for understanding human communication (Turner 2014: 97); Turner argues (Blended classic joint attention, s.a.): 
In classic joint attention, participants have an understanding of "the ground"; that is, they understand a great deal about "the speech event, its setting, and its participants" (Langacker 1985:113) without needing to refer to that understanding. Each of the participants understands that the other has a human mind; that each of them has a viewpoint on the conditions of space, time, participants, physical relationships, cultural situation, and so on, and that each knows that the other has such a viewpoint.

Moreover, as Sweetser rightly points out, the Ground includes "sharing and negotiation of viewpoint between Speaker and Hearer" (Sweetser 2012: 8). Exploration of viewpoint as a subjective and an intersubjective phenomenon is central to the theoretical and methodological approach introduced in Dancygier and Sweetser (2012). Sweetser underscores the ubiquitous nature of the phenomenon (Sweetser 2012: 13):

Data from all the relevant sources thus come together to push us towards a theory that includes mutual awareness of viewpoints between participants - and incorporation of addressees' and spectators' and readers' perceived viewpoints into cognitive perspectives of speakers, narrators, and writers. Intersubjective viewpoint construction is important at every level of communication, from speech gesture to literary narrative.

I argue that intersubjective viewpoint construction is central to the understanding of "Infectious", and is best investigated through the model of blended joint attention. Being a poetic and a media event simultaneously, "Infectious" already relies on a mental web for blended joint attention, since in the process of its reception we are "blending the scene of classic joint attention with other things that do not in fact fit that scene" (Blended classic joint attention, s.a.). Being a meta-parodic event, "Infectious" is further anchored in blended joint attention. I argue that blended joint attention is imperative in revealing the story's communicative intention as a product of intersubjectivity (cf. Sanders et al. 2013). Naturally, consideration of the "ground" is crucial for the blended joint attention examination of "Infectious"; therefore, I follow "from the Ground down" logic introduced in Sweetser (2012: 1), and begin my analysis of "Infectious" with a consideration of its grounding space.

\subsubsection{The Grounding Space of Infectious: ground and grounding context}

Turner (2014) points out that "the ground" seems to us basic and immediate, but [...] underlying it are vast blending webs [...]; and it "can be expanded to help us handle even 
more complicated mental verbs" (Turner 2014: 98). Drawing on the previous scholarship on the topic of "ground" and subjectivity, Ferrari \& Sweetser (2012) further develop the understanding of the structure of the implicit Ground in their concrete account of subjectification, using the Basic Communicative Space Network (henceforth BCSN). They define the Ground as involving (Ferrari \& Sweetser 2012: 48-49):

1) a Ground Base Space, or Real Space, incorporating the real Speaker (S) and Hearer (H) in their spatiotemporal setting; 2) one or more Epistemic Spaces: understanding of S's and H's belief's and reasoning processes, which are also background to the communication; 3) a Speech Act Space of performed speech interactions (e.g. this is a statement or a question); 4) a Metalinguistic Space of shared linguistic forms that can be referenced if chosen usages are brought into consciousness or disputed.

Ferrari and Sweetser (2012) argue that the more detailed account of the Ground helps to elucidate the interaction between Content Space Network and the Ground within the BCSN. Crucially, they do not include the consideration of a broader grounding context. In her brief overview of the role of context in determining viewpoint, Sweetser (2012) rightly points out that the list of contextual factors affecting the construction of viewpoint can be rather long; at the same time, she underscores the necessity to focus on the aspects of context relevant to consideration of a certain type of data or modality (Sweetser 2012: 17-18). The crucial role of the context for the conceptual blending analysis of a poetic text is underscored by Freeman (2005), who argues that any imaginative text can prompt multiple readings depending on "the particular contextual, cultural domains of the utterance, the utterer, and the receiver at a given point in time" (Freeman 2005: 29). Hutcheon (2000: xiv) points out that parody is intensely contextand discourse-dependent. Hence, while adopting Ferrari and Sweetser's Ground model as basic, I argue that the analysis of "Infectious" as a rather complex meta-parodic event of communication, requires looking beyond the basic and immediate ground to include the grounding context (as understood in Hougaard \& Oakley 2008, Oakley \& Coulson 2008, and Chilton 2008, in particular); or in other words, a number of relevant local, genre, cultural and historical frames and networks. Chilton (2008) emphasizes the relation of grounding context to genre; he argues that consideration of grounding leads 
us to a better understanding of discourse constraints and thus to the meaning construction behind discourse. Indeed, the Grounding Space of Infectious can be seen as incorporating the genre knowledge - "the type of knowledge that people need to have about language, cognition and communication" (Steen 2011: 28-29), or to be more precise, as a certain combination of values of the three sets of variables - 'context', 'text/situation' and 'code'. Steen views genre knowledge as a behaviour-regulating notion, which "constrains and specifies the broad notion of 'discourse'", i.e. as a combination of the short-term knowledge schemas (linked to long-term knowledge schemas) that are constructed and monitored in production and reception as we engage in discourse processing of a certain genre event (Steen 2011: 28-30). Thus, in the Grounding Space "producers and addressees have a repertoire of this type of genre knowledge that is more or less developed, and in the diverging ways, in accordance with their communicative needs" (Steen, 2011: 34). I draw upon Oakley and Kaufer (2008) to introduce three "porous" circles of the Grounding Space for Infectious (Figure 1).

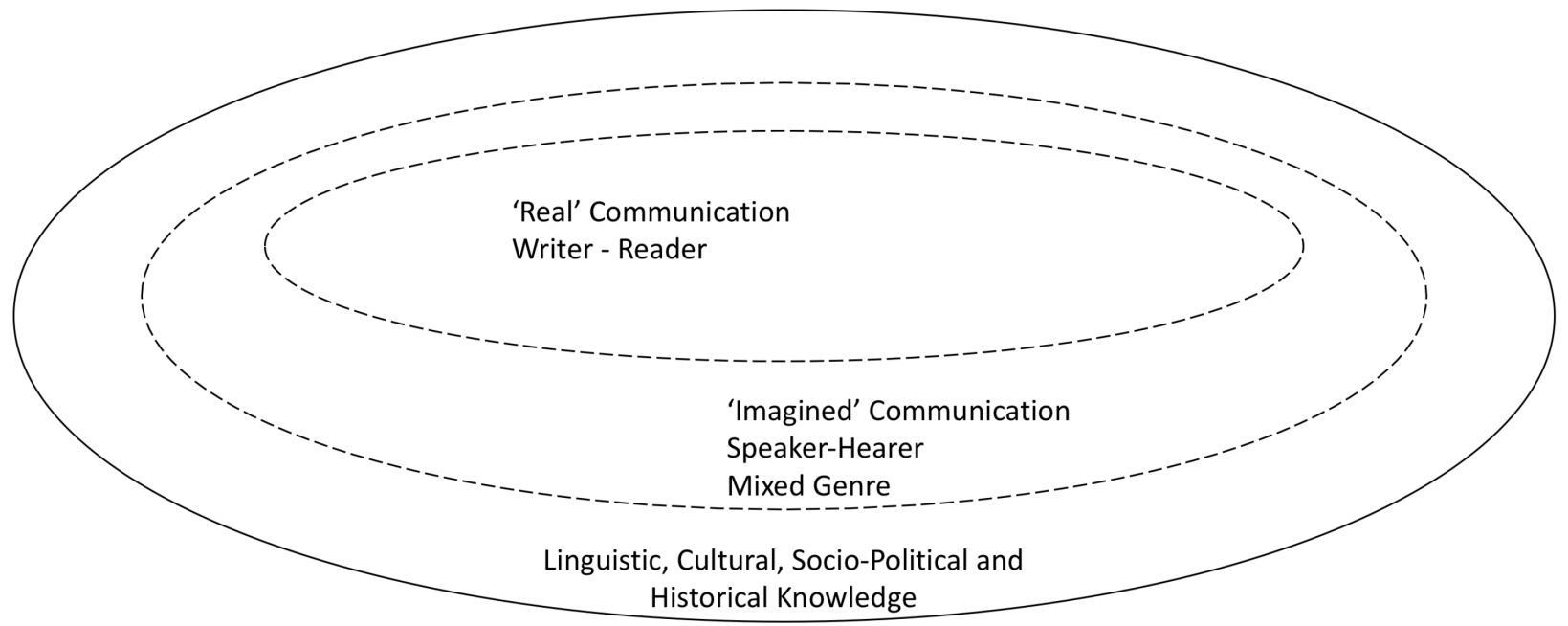

Figure 1: Grounding Space

The inner circle presents the author of the text and the instigator of the parody, Dmitry Bykov $^{\text {iv }}$ - a prominent Moscow-based writer, journalist, critic and media personality, and the reader, the perceiver of the parody - the audience of 'Novaya Gazeta' - a major national liberal newspaper. Although often viewed by Western intellectuals as a member 
of the liberal opposition movement, mainly due to his "Citizen Poet" (2011-2012) project and participation in anti-Putin street protests of 2011-2012 (Polonsky 2012: 60-61; also see Read Russia 2013, s.a.) at the same time Bykov is labelled by the prominent Russian Studies scholar Rosalind Marsh as a nationalist revanchist, who has "contributed to the wider dissemination of 'patriotic' literature" (Marsh 2007: 558) and "advocates a strong state and imperial expansionism" (Marsh 2011: 160). Marsh notes that in 2006 Bykov became the first winner of the Russian National Big Book Prize, introduced by Putin's administration and financed partly by the state and partly by private business, for his study of the life and work of Boris Pasternak (Marsh 2007: 69). Marsh also sees Bykov as one of the writers who "are constantly experimenting with new genres" and a representative of the 'blurring of genres' process in Russia, where "the frontiers between high and low culture are becoming blurred", methods of mass culture are rehabilitated and one is more prepared to embrace commercialism (Marsh 2007: 99)

The middle circle introduces the 'genre' of "Infectious". Since the text realises elements of at least five genre frames - newspaper essay, civic poetry, lyrical text, parody, and travel writing, in this circle we will have the integration of the elements for multi-level mental 'genre' models. The circle represents the imagined communicative scenario (the Speaker and the Hearer). The genre of parody will presuppose activation of the 'target of parody' mental space. The latter is represented by the audience of the contemporary Kremlin-sponsored media discourse related to Putin-Medvedev nation-building project. The project underlies a new constructed Russian ideology of nationalism (cf. Anderson 2006; Chaisty \& Whitefield). Having grounded their analysis in original survey data collected at regular intervals: 2001, 2003, 2007, 2009 and 2014, Chaisty \& Whitefield argue that "Nationalism has become the dominant discourse in Russian politics in the 2000s. Ideas about the nation and patriotism are part of the political mainstream" (Chaisty \& Whitefield: 2). Nationalist Kremlin-sponsored media discourse is viewed by scholarship as promoting the dominant features of Russianness, i.e. the "commitment to [...] Russian culture: language, history, values of statehood and patriotism, the idea of strong and great Russia, uniqueness of the Russian civilization" (Panov 2010: 93), as 
well as 'national unity'v as a feature which distinguishes Russia as a type of community (Hutchings \& Tolz 2015: 16). Hutchings and Tolz (2015) argue that Kremlin-sponsored media discourse also reflects "the stubbornly persistent tendency of the state-aligned media to construct Russian identity in relation to the western [...] 'other'" and "a transparent effort to exploit European 'misfortunes' to Russian advantage" (Hutchings \& Tolz 2015: 7); thereby framing Britain negatively as the 'other' and the 'enemy'.

We understand parody "because we share certain assumptions or cultural codes with the encoder" (Hutcheon 2000: xiv). In the outer circle of the grounding space, there will be a set of culturally shared frames and cultural networks ${ }^{\text {vi }}$ related to broader Russian pre-Soviet, Soviet and post-Soviet discourses, with the SELF-OTHER frame playing a central role. The outer circle contains information stored in the long-term memory of the writer and the reader and related to their previous education and experience, their linguistic, cultural, literary, poetic, metaphoric, socio-political and historical knowledge to varying degrees and complexities. This circle will include a cultural network of Russian civic poetry - e.g., poetry by Nekrasov, Mayakovsky, Evtushenko, Vysotsky (on Bykov and civic poetry, see e.g., Barkovskaya 2014; Malykhnina 2014; Smith /forthcoming/), along with a broader mental representation of Russian and Soviet literature as historically playing a significant role in post-Soviet everyday life (see e.g., Cavanagh 2010; Kuhiwczak 2006; Luytskanov et al. 2014; Smith /forthcoming/). Furthermore, among other cultural models, the Grounding Space will incorporate elements of 'Russia', 'Native Land', 'Slavophilism', 'Intelligentsia', and 'Patriotism' culturally-shared frames, examined by Stepanov (2004) from the cognitive linguistic and historical perspectives as key Russian national konstanty (constants). The dimensions for Russian/Soviet imperial past (see Etkind 2011; Hutchings \& Tolz 2015) and traditional Russian attitudes to foreigners (Rogachevskii 2006) will be profiled especially in their relation to the post-Soviet literature, culture and politics (cf. Smith /forthcoming/). Rogachevskii (2006) labels such traditional attitudes to foreigners as 'assumptions'. He points out that they are "determined by a number of geo-political and cultural factors" as well as by linguistic 
(Slavic languages) and religious (Orthodox Christian) aspects, and "have never replaced and/or counterbalanced one another in keeping with every significant historical change". Such assumptions include "an East versus West divide" and "a sealand divide", by which a 'continental' state Russia is opposed to the 'oceanic' USA and UK" (Rogachevskii 2006: 31).

\subsection{Considering irony as a parody's rhetorical miniature: the inter-relation of Ground,}

\section{Content and Viewpoint spaces, and the concept of Attention}

Ferrari and Sweetser (2012) underscore that central to our understanding of any communication form and viewpoint arrangement is "grounding of the Content with respect to a ground" (Ferrari \& Sweetser 2012: 49). Naturally, this tenet extends to our analysis of meta-parody. Irony is viewed as a parody's rhetorical miniature (Hutcheon 2000: xiv), hence Tobin and Israel's study (2012) of irony as a viewpoint arrangement is of particular interest to us. Similar to Ferrari \& Sweetser (2012), Tobin \& Israel (2012) anchor their analysis in mental spaces theory (Fauconnier 1985), but as distinct from the former, Tobin \& Israel's account includes looking into the relationship between the viewpoints of participants constructed for both real and imagined communicative events. Tobin and Israel (2012) introduce a certain configuration of the Ground, Content and Viewpoint spaces to explain irony as a viewpoint effect and analyse irony as a network of mental spaces involving a blend. Crucially, they underscore that an ironic meaning does not emerge in the Content Space but rather in the Viewpoint Space, with the emergence of irony supported by the network as a whole; the finding confirming one of the central arguments of the blending theory (Fauconnier \& Turner 2002). Tobin and Israel explain (Tobin \& Israel 2012: 35):

Like Coulson, we thus see irony as involving a kind of a blend; however, in our account, the blending takes place not in the Focus Space where the proposition is expressed, but rather in the Viewpoint from which an expressed proposition is accessed. The experience involves the same propositional content being assessed simultaneously from two incompatible viewpoints, one of which encompasses the other. This is what makes irony different from the experience of simply being in two minds about something. The ironic effect itself appears to arise from the way a whole construal (including an expressed proposition in focus from some viewpoint) itself becomes an object of construal. 
It seems that, like irony, parody involves a kind of "a dynamic blended construal of an event from two distinct viewpoints" (Tobin \& Israel 2012: 31). As Hutcheon argues: "Its [parody's] voices neither merge nor cancel each other out; they work together, while remaining distinct in their defining difference" (Hutcheon 2000: xiv). The understanding of the nature, affordances and constraints of the voices' joint work appears to be key to interpretation of a certain work as meta-parodic vs parodic. Assuming that irony is central to parody construction (Hutcheon 2000 and 2002), can the dynamic blended construal central to ironic interpretative process (as described by Tobin and Israel 2012) constitute the central cognitive mechanism for parody? Does the overall parodic interpretative process differ from ironic interpretative process? If yes, then, how? Crucially, Tobin and Israel (2012) offer the explanation of the ironic interpretative process as anchored in the concept of attention.

Acts of ironic understanding in general, including verbal, dramatic, and situational ironies, involve a type of dynamic reconstrual in which attention "zooms out" from the focused content of a mental space to a higher viewpoint from which the original Viewpoint Space is reassessed. In this interpretative process, a meaning is accessed from one viewpoint (the ironised) and then, simultaneously or a little later, re-assessed from a higher viewpoint (the ironic).

I argue that focusing on the construction of blended joint attention for the parodic interpretative process, while drawing upon Tobin and Israel's study can help to provide the answers.

\section{Blended joint attention in viewpoint blending network of Infectious}

\section{Overview}

In the following sections, while building upon my analysis of the Grounding Space, I present more specific and evidence-based answers to the research questions, introduced at the beginning of this article. I approach the analysis in the following mode:

1) Question: what specifically in the viewpoint construction behind Bykov's "Infectious" makes the reader regard one of the voices (viewpoints) as more or less, or equally, authoritative? 
I analyse the specific viewpoint configuration - the network of viewpoint blends grounded in the Russian 'Self-Other' culturally specific frame, as the core one. In so doing I start from zooming into the construction of the Russian 'Selves' as viewpoint blends and a product of intersubjectivity (МЫ 'WE' viewpoint blends), underlying "Infectious". I subsequently move to the analysis of the Russian 'Selves' as jointly attending to the objects of SELF space (Russia), focusing on viewpoint blends central to the understanding of "Infectious". These viewpoint blends form a network, where the understanding of "Infectious" depends on a number of cognitive operations, central to which is the reader's attention moving through the network.

2) Question: are there certain types of linguistic (multimodal) viewpoint markers that trigger or constrain meta-parodic viewpoint blending network construction?

I consider viewpoint markers of various types - triggers for viewpoint blending construction - in their interaction: 1) linguistic clues - from a phoneme to discourse as a whole; 2) prosodic features - rhythm and meter; 3) and visual markers - a caricature picture of "Infectious". These markers trigger the construction of multiple construals - deictic, multimodal, ironic, 'expository question', metaphoric, metonymic, counterfactual, intertextual, poetic, polyphonic, parodic and metaparodic conceptual blends, all contributing to the construction of viewpoint blends, cascades of viewpoint blends, and the network of viewpoint blends underlying "Infectious" as a whole.

3) Does meta-parodic viewpoint blending network construction differ from parodic and ironic networks? If so, how?

I attempt to elucidate the difference between the ironic and parodic networks' construction, through demonstrating how various construals - deictic, multimodal, ironic, 'expository question', metaphoric, metonymic, counterfactual, intertextual, poetic, polyphonic, parodic and metaparodic conceptual blends - work together to produce the emergent meaning of Infectious, and how the reader's attention moves through the viewpoint network of Infectious. 
4) What does the analysis of Bykov's meta-parody as a viewpoint blend tell us about critical media and literary discourses in Russia, as well as about the productivity of blended joint attention as an analytical tool?

In the 'Discussion and conclusion' section, I provide the answer to this question, while stating that critical media and literal discourses in contemporary Russia assist in forming Russian national identity and are rather contradictory and ambiguous message-wise. I also argue that blended joint attention constitutes a productive analytical tool for examination of (meta-) parodic viewpoint networks such as "Infectious", as well as for achieving a viewpoint markers and viewpoint blends typology for such networks.

\subsection{Linguistic viewpoint and viewpoint blending in language}

Hutcheon points out: "Parody is indeed in the eye of the beholder. But beholders need something to behold; we need signals from the text to guide our interpretation" (Hutcheon 2000: xvi). Indeed, we need signals to recognise voices of parody and interpret them as incongruent and evaluate them as superior vs subordinate, or may be equal; in other words, we need markers, which would prompt our construction of viewpoints and relationship between them. Sweetser (2012: 4-6) summarises the range of linguistic forms for English - markers of viewpoint as belonging to the following categories:

1. Where the Speaker and Addressee are assumed to be, and what they are thought of as being able to see, be able to reach, and so on (various special terms);

2. When the Speaker and Addressee are assumed to be (grammatical tenses and temporal terms);

3. What the Speaker and Addressee are assumed to know, think, presuppose, and be able to calculate mentally about whatever mental space is involved (determiners, pronouns, address forms, or honorific markers, connectives and evidential markers, presuppositional lexical items);

4. What the Speaker and Addressee feel about the contents of the relevant spaces - how they evaluate them affectively, culturally, and so on (framing and affective markers).

As Sweetser (2012) argues "many of these forms might better be analysed as in some 
way negotiating Speaker and Hearer viewpoints, more in line with Verhagen's (2005) intersubjectivity than with the hypothesis that they simply mark Speaker viewpoint" (Sweetser 2012: 6). Any intersubjectivity configuration involves some sort of blending network for joint attention (cf. Turner 2014). From the very beginning, it is clear that "Infectious" offers at least two sets of Speaker and Hearer - "real"vii and imagined, negotiating viewpoints, hence I need to look into linguistic and multimodal representations of this complex viewpoint arrangement. Turner (2014) points out that "all languages have many expressions for expressing viewpoint, but they also have plenty of expressions for expressing blends of viewpoints" (Turner 2014: 263). I believe that the examination of the latter should help in establishing the specificity of meta-parodic viewpoint blending network.

\subsection{Infectious: SELF and OTHER}

\subsubsection{The scene of blended joint attention}

The Grounding Space of "Infectious" supports the setting up of the story's scene of blended joint attention. Being a media communicative event and a fictional work at the same time, Bykov's "Infectious" blends a communicative scene for a newspaper essay with a communicative scene typical for a literary and poetic work; the resulting blend is further mapped with the imagined communicative scene central to the story. The emergent complex blend has various participants - Selves, and the object of joint attention of these Selves - the SELF and the OTHER, namely Russia and Abroad/Britain. I start looking into the Selves/SELF and the Others/OTHER from the examination of deixis, which has been analysed by the scholarship as a construal central to viewpoint arrangement in media and literary discourses and a discourse organising device often guiding our interpretation of other non-deictic relevant construals (see e.g., Chilton 2014; Dancygier \& Sweetser 2012; Grenoble 1998; Hart 2010; Paducheva 2011). 


\subsubsection{Deixis and discourse: information packaging}

While investigating deixis in Russian media discourse, Grenoble (1998: xi) underscores its crucial role in information packaging.

Information packaging involves a use of primary deictics (temporal, spatial, person) in signalling information structures in the knowledge, focus, and thematic deictic dimensions. These latter dimensions can be grouped together as signalling information status and include both deictic and non-deictic elements, varying from the Russian discourse particles to verbal aspect.

Grenoble (1998) argues that information packaging can be properly interpreted only as a whole, at discourse level, where the discourse's information structure can be analysed in accordance with two key dimensions of deixis - +/-proximal and +/inclusive. Grenoble points out that both can be embraced by a single distinction of $+/-$ distance, accounting for both primary spatio-temporal and secondary thematic and focal relations. She sees 'distance' as "a definitive feature of perspective, such that + distance will signal external perspective, or a non-congruence with the person deictic centre, and-distance a convergence with the person deictic centre" (Grenoble 1998: 259; Grenoble sees this approach as promising for viewpoint analysis (cf. Hart 2010, Kopytowska 2013, Cap 2014). The interrelated notions of deixis, distance, discourse and viewpoint are central to Chilton's Deictic (Discourse) Space Theory. Chilton (2014) investigates discourse space as a deictic space introducing the 'conceptualisation' model rooted in geometry, "built on the idea that not only any and all utterances are relativized to a minimal communication pair (speaker and hearer) but also that they integrate three conceptual dimensions", namely: attentional distancing from $\mathrm{S}(\mathrm{d})$, temporal distancing from $\mathrm{S}(\mathrm{t})$ and epistemic-modal distancing from $\mathrm{S}(\mathrm{m})$, where S stands for speaker, self and experiencing subject (Chilton 2014: 14).

I adopt Grenoble's and Chilton's logic in approaching the analysis of discourse space as primarily a deictic space. I make use of Grenoble's notion's of deixis as playing a big role in discourse information packaging and signaling discourse information status. The former seems to provide a good foundation for revealing both deictic and the related non-deictic discourse construals; and the latter is useful for examination of a 
communicative intention as parodic or meta-parodic.

\subsubsection{Construals for space}

The opening lines of "Infectious" trigger the process of SELF (Russia) vs OTHER (Britain/Abroad) conceptualisation, as both the Speakers' and Hearers' (Selves') spatial setting and their object of blended joint attention through labelling the respective spaces (our people) and внешний мир на бескрайнем блюде (the outside world on the endless earth [limitless plate]). Наши люди (our people) signifies the SELF Space, through profiling the facet for 'Russian people'. 'Our people' marks the SELF Space as the Speaker's location and a deictic centre of the deictic space of "Infectious". Such a viewpoint construction is further supported by the deictic forms for SELF Space здесь (here), к нам (to us/our place), у нас (at ours/our place); the OTHER Space is verbalised by the deictic terms - там (there), mуда (to there), $y$ них (at theirs/their place).

As the story unfolds, the OTHER Space is further conceptualised through the terms labelling metaphoric and metonymic construals, and containing the semantic component of 'geography' - британский флаг (British flag), испанка (Spanish), африканеи (the inhabitat of Africa), Китай (Chinese), голландский (Dutch) и стокгольмский (Stockholm), тайванский (Taiwanese) и гонконгский (Hong Hong); or marking one of the most salient details of the OTHER Space - the most famous British street Пикадилли (Piccadilly), or relying on the core metaphoric construal of "Infectious", which labels the OTHER Space as infectious - заповедник зараз (the reserve for infections). Bykov emphasizes the spatial juxtaposition of Russia to the whole other world, which nearer the end of the story is summarised by deictic всюдy (everywhere), and then is intensified by repeating the opening lines containing the expression внешний мир на бескрайнем блюде (the outside world on the endless earth [limitless plate]) at the very end of the story. 
The spatial focus of "Infectious" is also indicated by the deictic usage of the Russian unprefixed imperfective multi-directional verb of motion ездил (travelled) and the prefixed motion verbs - imperfective уезжать (move [leave]) and perfective прилетищь (come [arrive]), denoting spatial displacement. Consider.

Внешний мир на бескрайнем блюде разложил свои города. Прав Онищенко - наши люди не должны уезжать туда.

Я не три, не четьре раза ездил в ихние города, и о том, что у них зараза, я догадывался всегда. Возвращаясь в край колоколен, где двуглаво рулит тандем, я догадывался, что болен, - не вполне понимая, чем. Знать, покуда по Пикадилли беззаботно гулялось мне - заразили, мля, наградили. Влили в чай, поднесли в вине. А потом прилетишь обратно, влезешь в шлепанцы, снимешь фрак-все не так, а что - непонятно. Все как было - и все не так. The outside world has spread its cities out across the endless earth [plate]. Onishchenko is right - our people shouldn't move there.

Not three or four times have I travelled to their cities, and have always suspected that they breed a contagion. Upon returning to the land of bell towers, where the tandem steers two-headedly, I suspected that I was ill, not fully understanding what with. As I understand it now - while I was having a carefree saunter around Piccadilly, they contaminated, damn!, decorated me. They poured it into the tea, they put it in the wine. And then you arrive [come] back home, you put your slippers on, take off your tailcoat - everything is as it was, but everything is wrong. Everything is as it was, but completely different.

These three verbs of motion are especially important because they function as a discourse-organising device in "Infectious". Уезжать (move) frames the story appearing in the repeating opening and concluding lines. Featuring in the first paragraph of "Infectious", ездил (travelled) and прилетишь (come [arrive]) contribute to setting up the overall discourse spatial arrangement right from the beginning of the story. Being multidirectional, the verb ездил marks both the start and end points of 
motion through its 'going there and coming back' semantics, further intensified by не три, не четыре раза (not three or four times). The construction of the viewpoint here is affected by в ихние города (to their cities), which on the one hand marks the destination, but on the other hand conceptualises the destination as the OTHER Space. The use of prefixes with the Russian verbs of motion can conceptually shift the attention from the source from which a person is travelling to their destination and visa versa. The prefixed imperfective verb уезжать (move) marks the start point of motion, and the prefixed perfective verb прилетишь (come [arrive] by air) marks the end point of motion (Paducheva 2004: 373-374); hence both verbs signify the SELF Space as the focus of attention. Paducheva (2004) points out that the semantics of both verbs are rather unique as they leave the full motion scenario off-camera, meaning that even in their imperfective forms, these verbs retain their focus on the start or end point of motion, as opposed to the normal for imperfective verbs focus on the process. Paducheva (2004) explains that Russian прилетишь (as belonging to 'прийти' group) is different from the English verb 'come'. The latter (at least in its default meaning) requires the Speaker's and the Observer's positions to coincide; whereas Russian 'прилетишь' does not have this requirement (cf. Grenoble 1998: 46-52; Paducheva 2004: 374; Sweetser 2012: 9). Furthermore, Paducheva (2004) argues that the semantics of Russian прилетишь (come [arrive]) describes the commencing of some state of affairs, rather than a motion, which supports the spatial conceptualisation of the story's Speaker and Hearer as related to the story's participants attending to the state of affairs in the SELF Space.

\subsubsection{Construals for time}

The temporal configuration of "Infectious" is marked by the grammatical tenses present, past and future, and verbal aspectual forms - imperfective and perfective. The usage of grammatical tenses in "Infectious" is dependent upon the event time and discourse time (text-internal) and the coding (author's) and decoding (reader's) time (the text-external or utterance time), the terms used by Grenoble (1998). Although, as 
in any written text, there is a disjuncture between coding and decoding time in the real world setting, the imagined world of "Infectious" blends the text-internal and utterance time in the process of attending to the real world event of Onishchenko's (Russian Chief Sanitary Inspector) announcement on the danger of going to Britain, related to the swine flu epidemic, and the real world time of the release of the news broadcasts reporting it. It is evident that the event of Onishchenko's announcement belongs to the past in relation to the time of utterance. However, in the temporal viewpoint blend of "Infectious", the use of the present tense signifies both the temporal location of the imagined Speaker, the imagined Hearer, the implied Author, the implied Reader, and the temporal location of Onishenko, and the event of his announcement, all these Selves are jointly attending to (e.g., Прав Онищенко Onishchenko is right; Лишь Онищенко бвется Only Onishenko is striving to).

Interestingly, the only temporal deictic lexical term of "Infectious" is всегда (always). At the very beginning of the story, всегда (always) already prompts the temporal arrangement central to "Infectious", namely the story's attempt to compare and merge Russian (SELF) past, present and future in a single contemporary narrative. One of the ways "Infectious" achieves merging past and present towards the story's end is through comparing the SELF Space's past and present to each other, and simultaneously (through the blending of metaphorical 'ill-healthy' construals and the usage of past tense for the relevant verbs) to the OTHER Spaces implicit past and present, in the viewpoint blend. Consider:

Eсть ходынское многолюдье и лубянский есть маховик, есть басманное правосудье, петербургский есть силовик, тульский пряник (спасибо, Тула!), газ сибирский, таманский полк, азиатская диктатура, брянский шиш и тамбовский волк, астраханский курник слоеный и рязанский кисльй ранет, и архангельский гриб соленый - но российского гриппа нет. There is the Xodynskij mass of people and there's the Lubyanskij flywheel, there is the Basmannovij court, and the Peterburgskij silovik, Tula gingerbread (Thanks, Tula!), Siberian gas, the Tamanskij 
regiment, Asiatic dictatorship, the Bryanskij Shish and the Tambovskij wolf, the layered Astraxanskij kurnik, the Ryazanskij sour Pippin (apple), and the salted mushroom of Arkhangelsk, but there is no such thing as Russian flu.

This temporal viewpoint blend's construction is focused on the SELF Space and prompted by the usage of Russian lexical units labelling the past events (e.g., 'Xodynskij mass of people' and 'the Lubyanskij flywheel') and present events (e.g., 'the Peterburgskij silovik') as well as the verbs in the present tense ecmb ('is/exist') (cf. the analysis of temporal viewpoint blends integrating the past tense and 'now' in Nikiforidou 2012). Metaphoric linguistic representation - 'but there is no such thing as Russian flu' reinforces the blending structure by providing additional explicit focus on the SELF Space in its relation to the implicit OTHER Space.

\subsubsection{Construals for person}

\subsubsection{The imagined Speaker and the imagined Hearer}

"Infectious" uses reduced referential devices in the grammatical and logical subject positions as a core technique for conceptualising the imagined Speaker as part of the SELF Space vs the imagined Hearer as part of the SELF Space and the third party as part of the OTHER Space. A number of full referential devices наши люди (our people), внешний мир (the outside world), свои города (its own [the outside world's] cities), ихние города (their cities) is employed to indirectly provide antecedents for the reduced referential devices (on indirect antecedents see Paducheva 2012). The image of the Speaker is constructed through the first person singular $Я$ (I), linked to наши люди (our people) through the metonymic relation. $Я$ (I) travels to Britain (the OTHER Space) and having been infected with the Western democratic ideas, transforms into the Russian 'illocutive zero' - the implied subject of generalizedpersonal sentences, containing $2^{\text {nd }}$ person singular verbal forms (on the illocutive zero and pronouns see Paducheva 2012). Once the Speaker is cured by the healthier SELF Space, the illocutive zero turns into the illocutive pronoun TЫ (YOU singular)'. The Speaker labels 'YOU' as a chump, who has been played, and made to believe as a 
human being about himself. In the following lines 'YOU' permanently transforms into $M Ы(\mathrm{WE})$ and the respective zero forms.

Bykov uses illocutive pronouns $Я$ (I), ТЫ (YOU), $M Ы(\mathrm{WE})$ as well as the respective illocutive zero forms, functioning in generalised-personal sentences, to construct the imagined communicative scene between the imagined Speaker and the imagined Hearer (on illocutive pronouns and illocutive zeros see Paducheva 2012: 27). While activating the implied addressee, Russian 'YOU' and the respective zero form also function here as the generalised 'I', meaning "You, in the way as I and any other person in my place" (Paducheva 2012: 28), signifying a certain kind of blend with 'I' and 'YOU' as inputs. The generalized-personal meaning of the second person retains a link with the primary addressee meaning: the semantics of this use includes the component 'I want you to put yourself in my place and imagine that everything I am saying about myself is actually happening to you' (Paducheva 2011: 29). This conceptualisation is further reinforced by the subsequent use of generalised $1^{\text {st }}$ person plural $M Ы(\mathrm{WE})$ as well as the respective zero form.

\subsubsection{The imagined Speaker, the imagined Hearer, and the Others}

Paducheva (2012) points out that Russian illocutive zeros function as both generalised and representative references. She stresses that in Russian language, illocutive zero expressing generalised 'I' and 'WE' is juxtaposed to the 'third person zero' observed for indefinite-personal sentences; the distance between these two zeros is always highlighted, and the 'third person zero' always implies human beings/people (Paducheva 2012: 39).

"Infectious" uses the Russian 'third person zero' in the subject position to activate the 'implied' THEY as part of the imagined OTHER Space; the conceptual link to the OTHER Space is provided through a metonymic relation of the 'third person zero' to 'внешний мир' (the outside world). The actual pronoun ОНИ (THEY) in the subject 
position appears only once in the middle of the story to metaphorically label people from the OTHER Space using the predicate nominative - заразы (sons of bitches [infections]) and лютый яд для таких, как мы (mortal poison for those like ourselves), thereby taking the implied juxtaposition - 'THEY vs WE' to its culmination. Paducheva argues that 'third person zero' does not signify that the implied subject is unknown, but that it is insignificant, with the potential of going completely off-camera (Paducheva 2012: 3132). Such insignificance of the implied subject (THEY) points out to the central position of SELF and the peripheral position of OTHER, bordering with the off-camera position in the second half of "Infectious".

\subsubsection{Self 'WE' viewpoint blends and expository questions}

Turner argues that in the ground "the self in the moment of communication is already a compression over a vast mental web of time, space, causation, and agency"; he underscores that the self in the moment of communication can put forward multiple and shifting implied selves, implied speakers and construct implied hearers, as well as a web of relations between them (Turner 2014: 103). Understanding of "Infectious" as ironic and parodic involves the construction of the imagined Speaker, the imagined Hearer, the implied Author and the implied Reader as part of the SELF (Russia) Space, as well as appreciation of both the compression and decompression processes behind such a construction. As shown in the previous section, the usage of Russian pronouns $Я$ (I), ТЫ (YOU), MЫ (WE) and OHИ (THEY) trigger the construction of the imagined Speaker as part of the implied Self, sharing the imagined Speaker's viewpoint (ironized and parodized) towards 'THEY'; with 'WE' and 'THEY' representing a viewpoint space, which can be labelled as 'pro-Russian/pro-Kremlin' vs 'pro-Western' (henceforth labelled as the Self WE (1) blend). However, "Infectious" uses the same pronoun $M b I(\mathrm{WE})$ to also signify a different 'Self' viewpoint blend. Consider the extract:

Из-за моря вернулась птаха, и в ушах у нее свистит: меньше гордости, больше страха, иногда беспричинный стыд... Вдруг кольнет незримое жало, как отравленная игла: хорошо бы власть уважала, а милиция - берегла... Где мы 
нынче? Делаем что мы? Как мы прожили двадцать лет?! Разумеется, все симптомы за неделю сходят на нет, потому что в России лето, машет сиськами молодежь, а родного иммунитета, слава Богу, не прошибешь. A birdie has returned from beyond the sea, and there is whistling in her ears: less pride, more fear, sometimes an unfounded shame... Suddenly an unseen sting, like an infected needle, would prickle [you] - it would be good if the authorities were respectful and the police were caring... Where are we now? What are we doing? How have we lived for twenty years?! Naturally, all symptoms pass within a week, because its summertime in Russia, young people are walking around flashing their tits, and your native immunity, thank goodness, will help you not to batter down.

$M Ы$ (WE) in this extract is used as a trigger for a 'WE' construction, signifying the Russian nation as a whole, which includes the Self of the implied Author. To demonstrate the difference between the two 'WE' constructions, in this particular extract "Infectious" switches from 'I'/generalised 'YOU' to referring to the imagined Speaker as 'a birdie' (the $3^{\text {rd }}$ person singular), thereby introducing the voice of the implied Author into the story. Once the Author's voice and the respective viewpoint has been introduced, "Infectious" uses 'WE' to construct the Self WE (2) blend, making the Reader to recognise the Self WE (1) as forming part of the Self WE (2) conceptualisation, on the one hand, and on the other hand, to acknowledge the difference between the viewpoints attached to these two Selves/two Wes. The latter set is represented by the imagined Speaker (ironised viewpoint space) and the implied Author (ironic viewpoint space), respectively. Such an acknowledgement constitutes a pre-requisite for the Reader's ability to decompress the Self WE (2) blend, necessary for the Reader's interpretation of the text as ironic and parodic (cf. the analysis of the implied 'author - narrator speaker' relation as perceived by the reader in the ironic text in Tobin and Israel 2012: 36-39; and the analysis of the selves - the implied writers' and readers' complex relations - in the ironic and satirical fictional stories in Turner 2014: 100-102). 
Furthermore, as the story of "Infectious" unfolds, the Self WE (2) blend is further enriched by the explicit construction of the implied Reader. Consider the extract.

Обещаем не ради фразы - не водиться, не брать взаймы, потому что они заразы, лютый яд для таких, как мы. Внешний мир угрожает гробом, повернемся к нему спиной: в этом мире лафа микробам, СПИД, холера и грипп свиной. Вы смеетесь, но этим смехом не сдержать иностранный грипп. Литвиненко туда уехал все видали, как он погиб? Там и воля, и трали-вали, и закон справедлив и крут, да. Но все, кто там побывали, обязательно перемрут. We promise not for the sake of the phrase - not to befriend, not to borrow money, because they are infection, a cruel, powerful poison for people such as us. The outside world threatens us with death, we turn our back to it: in this world so good for microbes, AIDS, cholera and swine flu. You are laughing, but you won't stop foreign flu with laughter. Litvinenko went there did everyone see how he died? There's freedom there, you know what I mean, and justice, strict law - yes. But everyone who has been there will definitely die.

The explicit recognition of the implied Reader is signified by switching from $T Ы$ (YOU the $2^{\text {nd }}$ person Singular) to $B D I$ (YOU the $2^{\text {nd }}$ person Plural). The Reader's implied ironic and parodic perception of the imagined Speaker ('You are laughing') supports both the decompression of the Self WE (2) blend, and simultaneously the compression process of constructing the richer Self WE (3) blend, as including the implied Reader into 'WE' - Selves. 'WE' are jointly attending to all the issues related to the SELF Space of Russia and Russian nation as a whole. Such compression/decompression operation supports the idea of joint responsibility for Russia's issues, thereby transforming the local ironic construals into self-ironic and unstable ironic construals (for unstable irony see Tobin and Israel 2012) at the larger discourse level. The 'expository question' viewpoint blends (as explored in Xiang \& Pascual 2016) play a key role in this transformation process behind "Infectious". Consider one more extract, incorporating the expository questions. Разве мы кому заносили вредный вирус с родного дна? Разве выползла из России эпидемия хоть одна? Озаботься, образованеи, напряги остаток ума: грипп - 
"испанка". СПИД - "африканеи". Из Китая пришла чума. Несмотря на посул гарантский, неуемен вражеский зуд - к нам завозят синдром голландский и стокгольмский синдром везут... Have we ever given anyone a harmful virus from our native soil? Has even one epidemic ever crept out of Russia? Consider this, oh educated one, strain the remainder of your mind: the flu - is a Spanish lady. AIDS is an African. The Black Death came from China. In spite of the promise with guarantees, the enemy's itch has not been calmed [is unstoppable] - they are bringing in Dutch syndrome and they are taking Stockholm syndrome here [to us] ...

The given extract triggers the explicit construction of the imagined Hearer as образованеи (oh educated one), and its subsequent mapping into the Self 'WE' (3) blend, resulting in the emergence of the Self WE (4) blend. The implied Author is constructed as very well-educated and as the opponent of the imagined Speaker through the 'illhealthy' metaphoric construal. The implied Reader summarises the implied audience of 'Novaya Gazeta' - a major national liberal newspaper, the audience, which is widely seen as well-educated. Therefore, the imagined Speaker's address to the imagined Hearer as 'oh educated one' can be viewed as constructing the 'implied Author - imagined Hearer' blend as well as the richer 'implied Author - imagined Hearer - implied Reader' blend through the explicitly signified and "planned [by the author] participation of the reader in the interpretation of the text" (Paducheva 2011: 33).

Central to the 'WE' blending process is viewpoint construction and viewpoint shifting, with the expository questions constituting the core construal operation. Pascual (2014) argues that through highlighting the fictive dialogue set-up, its fictive speaker and fictive addressee, such fictive interaction devices as 'questions' and 'question-answer' construals function as discourse and argumentative strategies (Pascual 2014; Xiang \& Pascual 2016). Xiang and Pascual (2016) explore and define expository questions "as involving a viewpoint blend (Dancygier \& Sweetser 2012), integrating the perspectives of the writer, the assumed readers and the discourse characters" (Xiang \& 
Pascual 2016). All three extracts from "Infectious" given above feature the expository questions. The expository questions' role here is two-folded. These questions highlight the difference in viewpoints initially constructed for the 'imagined Speaker' Space vs the 'implied Author' and 'imagined Hearer' spaces, i.e. the 'barely literate' Speaker vs the 'thoughtful observer' Author and the 'educated' Hearer, - contributing to the construction of the ironised vs ironic viewpoint spaces, respectively. Simultaneously, as perceived at the larger discourse level, these questions function as a key strategy in setting up the blended joint attention scene, through mapping the Selves of "Infectious" - the imagined Speaker, the implied Author, the imagined Hearer, and the implied Reader in their attending to and communicating about the past, present and future of Russian people and Russia. The questions construct the implied Reader as acknowledging the irony of "Infectious" ('You are laughing'), but at the same time they invite the Reader to go beyond the superficial ironic level and engage in a more serious consideration of the SELF Space's issues highlighted by "Infectious" as a whole, to construct the 'parodised' and 'parodic' viewpoint spaces and access the relation between them. In order to do so, the Reader has to focus on and evaluate the Objects of Blended Joint Attention and their viewpoint relationships with the Selves.

\subsubsection{The Selves and the objects of blended joint attention in parodised and parodic} mental spaces of "Infectious"

\subsubsection{Viewpoint blend (1): Onishenko's recommendation and its audience as ironic construal}

The Self (MЫ 'WE') construction, comprised of the Selves verbalised by $Я$ (I), $B D I$ (YOU) (Singular and Plural), and $M b I$ (WE), functions both as the blended selves network representing the participants-interlocutors of the blended communicative scene of "Infectious" and as the objects of the blended attention of these blended selves. "Infectious" constructs the objects of the selves' blended joint attention as a network of mental spaces with irony constituting the core construal operation. The ironic interpretation of "Infectious" as a whole relies on the multimodal construal of the 
perception of the news item reporting the Onishchenko's announcement. This multimodal construction is triggered by: 1) the verbal reference to Onishchenko in the repeating opening and concluding lines Внешний мир на бескрайнем блюде разложил свои города. Прав Онищенко- наши люди не должны уезжать туда. (The outside world has spread its cities out across the endless earth [plate]. Onishenko is right - our people shouldn't move

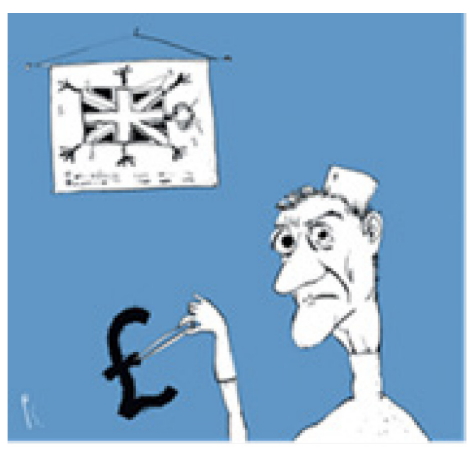
there.); 2) the verbal reference to Onishchenko in the middle of the story Лишь Онищенко бьется, чтобы перекрыть роковой просвет (Only Onishenko is striving to close the fatal gap [chink of light]: you see, there aren't any microbes among us); and 3 ) by the caricature visual image of him (on visual images informing verbal irony see e.g., Burgers et al. 2013; on multimodal blends see Forceville 2013; Sambre 2013). There is nothing peculiar in Onishchenko's announcement regarding the swine flu epidemic in Britain since it is no different to a foreign travel advice published on the daily basis by the British government or any other Western government. Neither the announcement is directly connected to the idea of democracy, nor to Putin-Medvedev's nation-building project. "Infectious" links it to both through constructing the Selves' joint attention configuration and imagined reaction to this news item. The Selves' perception of the Onishchenko's announcement is conceptualised in the imagined world of "Infectious" through: the metaphor construal of the OTHER Space's ideas as infection; the intertextual construal of 'our (Soviet and post-Soviet) people'viii moving abroad/leaving for good, and travelling abroad; and through profiling Onishchenko as a person with the authority, who forbids Russian people's moving abroad and free travel, while acting in their own interests. Considered on its own, this multimodal construal presents a case of unstable irony - "an irony that offers no final interpretation" (Tobin \& Israel 2012: 26). Although, the Reader assesses the representation of Onishchenko's recommendation in the 'real world' and 'imagined world' mental spaces as incongruent, and hence rather funny due to the extensions and obvious exaggerations provided by the ironic viewpoint space, the intended message of this local irony is not clear (cf. Tobin \& 
Israel 2012: 40-43). In the real world of Onishchenko's recommendation swine flu is a serious illness; the recommendation to temporarily refrain from travelling has nothing to do with the concept of Soviet 'Iron Curtain'; moreover, Onishchenko is just a Sanitary Inspector, albeit the Chief one, and has no authority as far as the Russian foreign politics or freedom of travel in the political sense are concerned. The 'Onishchenko's recommendation' ironic blend - Viewpoint Blend (1) - only works if the Reader accesses the multimodal construal from the broader contextual perspective and realises that the announcement is used as a departure point for constructing and mocking the pathology of the media audience's perception of the Kremlin-sponsored discourse related to the nation-building project. It only works if the Reader appreciates that in the parodic space the Selves treat the Onishchenko's recommendation as constituting part of the latter discourse. Such Reader's interpretation is achieved through shifting the Selves' blended joint attention from the Onishchenko's announcement to the objects of Russia and Russian nation vs Abroad (SELF vs OTHER Spaces).

\subsubsection{Viewpoint blend (2): Selves' knowledge and commitment within the metaphoric} construal of OTHER's ideas and values as infection

The shift in the Selves' attention to the objects of Russia and Russian nation vs Abroad is triggered by a number of the epistemic-modal and deontic-modal construals signifying the Selves' attitude towards the OTHER Space. "Infectious" is framed by the deontic construction presented as the Selves' agreeing with Onishchenko's prohibition for the Russian people to move abroad in the opening and concluding lines не должны уезжать (must not leave [Russia]). The argumentation for this Selves' statement is activated through the metaphor 'democratic ideas are infection' and 'Russia is a healthy and healing place', and the Selves' retrospective metaphorical assessment of multiple travels abroad and their perception of Russia and the impact Russia has on them, upon their return. The freedom which the Selves experience in the OTHER Space and the related conceptualisation of themselves as a human being with rights, who the authorities respect and care for is metaphorically construed as illness. This 
metaphoric construal functions as a viewpoint blending construal. The Viewpoint Blend (2) emerges through the integration of shifting modalities (epistemic and deontic) throughout the story. The modality of uncertainty and possibility of the Selves' being infected in the OTHER Space and thus feeling ill in the SELF Space is constructed through a modal verb догадывался (I thought [guessed]) and a modal word знать (It seems [I think I know]). The modality shifts to expressing certainty through the use of a modal particle ведь. Grenoble (1998) points out that Russian modal particles have no direct English equivalent as they are void (or almost void) of referential or lexico-semantic meaning, and are to be understood in terms of their discourse and pragmatic functions. She sees the particles as deictic devices, which can mark saliency of participants or foreground/background relations of events; moreover, she underscores that such particles can serve as cohesive ties, at the same time signalling the boundaries of topical units (Grenoble 1998: 21-26). Bedb functions as an emotive and expressive device enhancing the meaning of the sentence incorporating it. When $в e \partial b$ is used in the clause starting with conjunction $a$ (but) it works to foreground the meaning of this clause in relation to other parts of the complex sentence (see e.g., Znamenskaya 1985). Consider:

Не впервой под британским флагом воровские творить дела: ть-то все объяснял джет-лагом, а ведь это болезнь была! Ты купился, как лох, на "велкам", в заповедник зараз полез - возомнил себя человеком, а ведь это болезнь, болезнь. Not for the first time under the British flag have thievish goings on taken place: you yourself put it all down to jet-lag, but you really had this illness you see! You went for it, like an idiot, the "welcome", you went into the nature reserve for infections, you believed yourself a human being, but this was a disease, a disease.

The use of statements incorporating ведь marks the shift to the construction of the viewpoint of the desired world of a true 'patriot'. In addition to не должны уезжать (must not leave [move there]), deontic modals of "Infectious" help to construct the 
Selves' 'desired world of patriotism'. The construction is triggered through the use of Russian verb обещаем ([we] promise), as well as the future tense verbs and a modal particle nусть нас убьют (let them kill) in the concluding statements. Consider.

Обещаем не ради фразы - не водиться, не брать взаймы, потому что они заразы, лютый яд для таких, как мы. Внешний мир угрожает гробом, повернемся к нему спиной: в этом мире лафа микробам, СПИД, холера и грипп свиной. We promise not for the sake of the phrase - not to befriend, not to borrow money, because they are infection, a cruel, powerful poison for people such as us. The outside world threatens us with death, we turn our back to it: in this world so good for microbes, AIDS, cholera and swine flu.

Не покинем родную липу, не свернем с родной колеи, не сдадимся чужому гриппу. Пусть нас лучше убьют свои! Onishchenko is right - our people must not move [leave for] there. We won't leave our native lime tree, we won't turn off our native track, we won't give in to the foreign flu. Would rather our own kind kill us instead!

"Infectious" constructs the Viewpoint Blend (2) as the ironic blend mocking the excessive patriotism related to the strategy of the Other's demonization, observed for the Kremlin-sponsored media discourse on nation-building. However, for the Reader to fully appreciate the ironic message constructed through the Viewpoint Blend (2), the Selves' joint attention has to be shifted again zooming into the situation and the issues of the SELF Space (Russia).

\subsubsection{Viewpoint blend (3): attending to the issues of the SELF space}

While attending to the state of affairs in Russia, "Infectious" forces the Reader to attend to the question of the Selves's responsibility for this situation and the related issues. It 
does so through construction of expository questions, the use of epistemic and deontic construals, as well as counterfactual construals.

In Section 5.2.6, I discussed the role of expository questions in the construction of the viewpoint blend - Self WE (4). The construction of these questions is also crucial for the emergence of the Viewpoint Blend (3) where Selves' are attending to and are critically evaluating the situation in Russia and the current formation of Russian national identity. As mentioned previously, these expository questions put forward the Self for the implied Author and the imagined Hearer, and invite the implied Reader to look beyond the superficial ironic interpretation and engage in the imagined communication on the current Russian situation. The expository questions help to create the imagined dialogue, in which the Selves 'Russian people' ask and answer the questions core to the process of their self-identification as a nation. The construction of this imagined dialogue serves as a discourse strategy for highlighting the degree of uncertainty and doubts expressed by Russians in relation to the arguments central to the parodised Kremlinsponsored media discourse (especially the ones related to the process of Others' demonization), as well as the resulting necessity to repeat these arguments in the attempt to re-assure themselves that these arguments offer the right interpretation of the current Russian situation. The use of the evidential marker все видали and the modal particle разве reinforce the mental representation of the Selves' uncertainty and the resulting reassurance seeking. Consider.

Вы смеётесь, но этим смехом не сдержать иностранный грипп. Литвиненко туда уехал-все видали, как он погиб? You are laughing, but you won't stop foreign flu with laughter. Litvinenko went there - did everyone see how he died?

Разве мы кому заносили вредный вирус с родного дна? Разве выползла из России эпидемия хоть одна? Have we ever given anyone a harmful virus from our native soil? Has even one epidemic ever crept out of Russia? 
Using the Zhuangzi text as a case study, Xiang and Pascual (2016) argue that the expository questions "are intersubjective in nature, as they are used to express the narrator's position on a particular issue, which is to be jointly attended to and resolved in the reader's mind". Furthermore, they rightly point out that the expository questions' "ultimate goal is to convince the reader of the provided or presupposed answer to the question asked by exploring the mutually shared information" (Xiang and Pascual 2016: 22). I argue that while looking into the presupposed answers of "Infectious", we are essentially looking into the story's communicative intention, thereby investigating the story's 'meta-parodic vs parodic' viewpoint blending structure.

The presupposed answers are conceptualised by "Infectious" through a number of construals - ironic, epistemic, deontic and counterfactual, metaphoric construals, among others. Key to the presupposed answers' conceptualisation is the Reader's cognitive ability and the necessity for the Reader to simultaneously construct and assess two contrasting mental spaces representing two parallel worlds for each of these construals - 'real-world' (ironised, epistemic, real/factual) and 'unreal-world' spaces (ironic, desired or counterfactual, respectively) in the process of the construals' interpretation. Drawing upon the mental spaces and blending theories (Fauconnier 1994; Fauconnier \& Turner 2002) as well as Sweetser \& Dancygier (2005), Chilton $(2014)^{\mathrm{ix}}$ uses his deictic (discourse) space model rooted in geometry for investigation of counterfactual and deontic meanings as mirror construals, and argues that the construals' interpretation is dependent on the respective epistemic conceptualisations (Chilton 2014: 262-263, 161-163). Tobin and Israel's (2012) account of irony presupposes a process of the ironic blend decompression in constructing the viewpoint of the 'ironised' space; it seems that the latter can also be considered as a kind of contrasting epistemic conceptualisation. I see the deontic and ironic construals examined above as contributing to the construction of the parodised space of the "Infectious" network. For example, the statement of наши люди не должны уезжать myдa 'our people must not move there' can mean that in the ironised/parodised mental 
space, Russians are currently moving freely; the promise обещаем не водится and повернемся спиной 'not to befriend the Others and let us turn our backs on them' can be decompressed and re-constructed as 'the Selves currently having a relatively friendly relationship with the Others'. The analysis of Infectious's counterfactuals ${ }^{\mathrm{x}}$ helps to draw a fuller picture. Consider.

Вдруг кольнет незримое жало, как отравленная игла: хорошо бы власть уважала, а милиция - берегла... Suddenly an unseen sting, like an infected needle, would prickle you - it would be good if the authorities were respectful and the police were caring...

Здоровее любых империй, удивительна и странна неприступная для бактерий обособленная страна. Не проскочат их вибрионы сквозь российское решето: если б твердо закрыть кордоны - не болел бы у нас никто. Healthier than any other empire, extraordinary and peculiar, inaccessible for bacteria, this country is isolated from all others. Their vibrio will not slip through the Russian sieve: and if only the cordons were firmly closed, no-one would be ill among us.

If decompressed, the counterfactual 'it would be good if the authorities were respectful and the police were caring' prompts the construction of the knowledge that Russian authorities do not respect the people and the police does not care in the parodised space, signalling the issues of the SELF Space. However, the second counterfactual dealing with the concept of freedom seems to present a more complex configuration. The lines incorporating the counterfactual prompt the construction of the metaphoric blends ${ }^{\mathrm{xi}}$ RUSSIA IS THE HEALTHIEST EMPIRE, RUSSIAN BORDER IS A SIEVE, and RUSSIA IS A SPECIAL CASE: удивительная, странная и неприступная для бактерий (wonderful, peculiar, detached, inaccessible for bacteria). They also trigger the construction of a counterfactual 'New Iron Curtain' - если б твердо закрыть кордоны - не болел бы у нас никто (and if only the cordons were firmly closed, noone would be ill here). The counterfactual scenario of the New Iron Curtain can be perceived by the Reader as a threat of repeating the Iron Curtain. At the same time the 
counterfactual works to indicate that in fact there is freedom in Russia: it is the Sieve and not the Iron Curtain. The described situation where Russia screens Western democratic ideas on their way into the country can be evaluated both negatively and positively.

The evaluation of the emergent metaphoric blend of RUSSIA AS A SIEVE and the related counterfactual scenario is conditioned by the context. Metaphoric and counterfactual construals of RUSSIA AS THE HEALTHIEST and STRONG (inaccessible for bacteria) EMPIRE will prompt the projection of the elements for Soviet imperial past "evoked with pride" in the parodised space (Hutchings \& Tolz 2015: 24) into the Viewpoint Blend (3). The lines will trigger the construction of Viewpoint Blend (4), necessary the Reader's successful interpretation of the given lines as well as of "Infectious" as a whole. The emergence of the meaning in Viewpoint Blend (4) will involve evaluating the lines from the perspective of the argumentation central to the parodised Kremlin-sponsored discourse related to the nation-building project through reconstructing of the perception of this discourse in the parodised mental space. Thus, the parodised space will include the knowledge that the Kremlinsponsored discourse juxtaposes 'imperial pride', and by extension 'strong and powerful Russia' to the 'Western 'democratic freedom'. While working jointly with other construals, the counterfactuals examined above are likely to prompt the construction of a rather ambiguous viewpoint arrangement. When considered at the level of Viewpoint Blend (4), where the Blended Selves are jointly attending and evaluating other key media discourse's arguments related to nation-building, metaphoric, deictic, intertextual, ironic and other construals also continue to work jointly producing the same 'ambiguous' viewpoint effect. Let us consider some linguistic units triggering such ambiguous viewpoint constructions. 


\subsubsection{Viewpoint blend (4): Selves' are jointly attending to the Kremlin-sponsored}

\section{media discourse's arguments}

Selves 'WE' as the object of blended joint attention is central to the Kremlin-sponsored media discourse's (henceforth 'the discourse') arguments promoting national unity. Such linguistic triggers as ихний (the illiterate version of 'their'), мля (a substitute for swearing work $\left[\mathrm{f}^{\wedge} \mathrm{ck}\right]$ ), лох (a sucker), образованеи (the slang version of 'the educated one') contribute to mocking the imagined Speaker of the "Infectious" as a barely literate, not very intelligent person, while parodising the pathology of the Russians' perception of the discourse. As the imagined Speaker gradually gets blended with other implied Selves of the story, "Infectious" signals sympathy towards the parodised blended Self through such lexical labels as nmaxa (a birdie), and человек (a human). Furthermore, as the story unfolds, 'WE' in the Self WE Blend (4) is framed as strong and resilient, living against all odds. Such evaluation is prompted by the constructions мы живем, а микробы нет (we live and microbes do not) and люди - да, а микробы мрут (people can live, but microbes die). Central to blending 'I', 'YOU' and 'WE' in the Self WE (4) Blend is the cultural frame of Russian Fool. As shown above, a number of construals in "Infectious" work to exaggerate the implied audience's oversimplified perception of the media discourse arguments related to patriotism. These construals take exaggeration to the point of absurdity, evoking the image of Russian Fool. The image of Russian Fool is derived from its folklore correlate 'Russian Ivan-the Fool', one of the central Russian national concepts (see e.g., Cherkasova 2011; Khriptulova 2014; Savitskaya 2013; Sinjavskij 2001). Sinjavskij (2001) points out to the ambiguous, paradox and contradictive nature the Russian Fool concept, underscoring the fluidity of the connotations attached to it. Savitskaya (2013) also notes the ambiguity underlying the Fool concept and highlights the contradictive nature of its main facets, namely: foolish, lazy, clever, wise, heroic, and the most fortunate. It seems that "Infectious" evokes the concept of Russian Fool in order to put additional stress on the multi-faceted and contradictive nature of the Russian nation (Selves). 
As the story unfolds, "Infectious" briefly attends to other discourse entities as part of the self-conceptualisation process. "Infectious" refers to Russian authorities (Putin and Medvedev) using the linguistic triggers где двуглаво рулит тандем (where the tandem steers two-headedly), хорошо бы власть уважала (if only the authorities were respectful), уважать не талант, а чин (to respect not talent, but rank), петербургский силовик (silovik [a member of a law enforcement agency] from St. Petersburg [Putin]). All these references resonate with the principle of choosing stable and strong state leadership over democratic governance, proclaimed during Putin's presidencies; furthermore, such a conceptualisation of Russian authorities as strong and stable reflects the idea of strong statehood (gosudarstvennost'), promoted by the discourse. This ironic conceptualisation is also in line with Putin's approved way of representing him and Kremlin, which is often summarised as: 'he does not want to be liked, he wants to be feared'xii. The idea of strength and fear is reflected in the story's reference to the Litvinenko Case. Consider the extract:

Вы смеётесь, но этим смехом не сдержать иностранный грипп. Литвиненко туда уехал-все видали, как он погиб? Там и воля, и трали-вали, и закон справедлив и крут, - да. Но все, кто там побывали, обязательно перемрут. You are laughing, but you won't stop foreign flu with laughter. Litvinenko moved there - did everyone see how he died? There's freedom there, you know what I mean, and justice, strict law - yes. But everyone who has been there will definitely die.

By creating this mental space for the Litvinenko Case, "Infectious" reminds the Reader of the unlimited power of the Kremlin, which is widely believed to be behind Litvinenko's murder in London in 2006. Through the given lines the imagined Speaker admits the virtues of the OTHER Space. However, the conceptualisation of Litvinenko Case as a political criticism remains undeveloped as the reference to Litvinenko Case rather serves to draw the blended joint attention to the image of 'WE' as demonstrating WE's 'foolish' excessive sense of patriotism and to the image of Kremlin as possessing unlimited power. Moreover, "Infectious" seems to take care in not undermining the 
image of powerful and fearful Kremlin. As mentioned above, Onishchenko's announcement constitutes a rather weak conceptual link to Kremlin, so his image is safe enough for the respective ironic and parodic construals not to be directly linked to the images of Putin or Medvedev. Instead, "Infectious" profiles the Selves' perception of Russia, their SELF Space. The story triggers the metaphorical, metonymic and intertextual conceptualization of Russia as: край колоколен (the land of bell towers) - a holy Orthodox place; где двуглаво рулит тандем (where the tandem steers twoheadedly), making a reference to Putin still being de-facto in charge of the country during Medvedev's rule. Using these linguistic triggers "Infectious" both foregrounds the Orthodoxy as a cultural-historical tradition and Russia as a strong statehood (gosudarstvennost'). Furthermore, numerous blends are constructed throughout "Infectious" to consistently support conceptualisation of Russia as родной дом and родная земля, meaning one's own, near and dear, native home and land. Stepanov (2004) explores the linguistic, cultural, literary, historical and philosophical roots of the concept родная земля, and defines it as part of SELF-OTHER culturally shared frame key to understanding Russia and Russians (Stepanov 2004: 86-210). Central to the concept of родная земля іs 'боль за свою землю' ([to feel] pain [in one's heart] for one's motherland/native land) which interweaves with 'pride and love for my own native land', its people, nature, language, etc. This is not something to be mocked or ridiculed easily. "Infectious" portrays Russia as a home where one can relax влезешь в илёпаниьь, снимешь фрак ([уоu] put your slippers on, take off your tailcoat), where one is protected by родной иммунитет (native/one's own immunity system), and can enjoy itself ловишь кайф от родных идиллий ([уоu] get a high from native idylls), as well as родное дно (native/one's own/near and dear bottom), родная колея (native/one's own/near and dear track), родная липа (native/one's own/near and dear lime-tree). All these ironic blends involve metaphoric, metonymic, and intertextual construals, with the latter three being especially creative and worth a closer look. 
These three blends evoke images created through infamous Russian classical writings: Maxim Gorky's "На дне" (The Lower Depths, literally: at the bottom, written in 1902), Vladimir Vysotsky "Чужая колея" (Stranger's [the Other's] track, written in 1973), and Sergey Esenin's "Береза" (The Birch, written in 1913). The birch tree is a symbol of the Russian natural environment, and 'береза' would normally constitute part of conventional expression 'родная береза', supporting the concept of love and nostalgia for Sacred Mother-Russia. "Infectious" substitutes a birch-tree with a lime-tree to motivate the Reader's activation of the second colloquial meaning for липа - a lie/fake/fraud, which projects a negative connotation to the resulting blend, adding to negative evaluation already evoked by allusions to Gorky's and Vysotsky's texts. However, while pointing to a number of the SELF (Russia) Space's issues, allusions to these classical texts also reinforce the ideas and emotions of love, nostalgia, pain and pride, shame and admiration, as experienced throughout all Russian historical periods: pre-revolutionary, Soviet and post-Soviet. The allusion to Vysotsky's poem is triggered by the lines: Не покинем родную липу, не свернем с родной колеи, не сдадимся чужому гриппу. Пусть нас лучше убьют свои! We won't leave our native lime tree, we won't turn off our native track, we won't give in to the foreign flu. Would rather our own kind kill us instead!

These lines take mocking the Selves' foolish (excessive) patriotism to its culmination, while at the same time highlighting Vysotsky's appeal to reject following the Others' track and to look for one's own unique path. Intertextual blends ${ }^{x i i i}$ behind these lines are further integrated to offer a possibility of various interpretations, criticizing the SELF's track (родная колея) and defining the OTHER's track as the wrong one, simultaneously. "Infectious" supports the perception of the SELF vs OTHER relation here as highly ambiguous, and rather promotes finding SELF's unique special path as a true patriotic act, thereby supporting one of the Kremlin discourse's core ideas. The theme of uniqueness also manifests itself in the following extract: 
Как сказал еще Маяковский, здесь, в России, особый быт. Есть тайваньский грипп и гонконгский, а московский не может быть. Есть ходынское многолюдье и лубянский есть маховик, есть басманное правосудье, петербургский есть силовик, тульский пряник (спасибо, Тула!), газ сибирский, таманский полк, азиатская диктатура, брянский шиш и тамбовский волк, астраханский курник слоеный и рязанский кисльй ранет, и архангельский гриб соленый-но российского гриппа нет. Злой орел или серп и молот осеняют наш гордый труд - но микробы тут жить не могут. Люди - да, а микробы-мрут. As Mayakovsky said in the past: here in Russia there's a special way of life. There is Thai flu and Hong Kong flu, but a Moscow flu just cannot be. There is the Xodynskij mass of people and there's the Lubyanskij flywheel, there is the Basmannovij court, and the Peterburgskij silovik, Tula gingerbread (Thanks, Tula!), Siberian gas, the Tamanskij regiment, Asiatic dictatorship, the Bryanskij Shish and the Tambovskij wolf, the layered Astraxanskij kurnik, the Ryazanskij sour Pippin (apple), and the salted mushroom of Arkhangelsk, but there is no such thing as Russian flu. The fierce eagle or hammer and sickle bless our proud labour - but microbes cannot live here. People can live, but microbes die.

"Infectious" alludes to Mayakovsky's words to foreground the idea of the Russia's uniqueness and uses the present tense to refer to both positively and negatively evaluated phenomena and events belonging to Russian past and present. The story also makes a reference to the coat of arms of the Russian Federation - a double-headed Imperial Eagle, which was derived from the earlier coat of arms of the Russian Empire (abolished with the revolution of 1917 and restored in 1993). The elements from the mental spaces for Russian past and present are compressed in the viewpoint blend to produce the emergent conceptualisation of Russia as empire, contemporary, unique, with sometimes foolish but strong people and strong leadership, holy and versatile, the image ultimately rather supporting one of central goals of Putin's nation-building project: "to merge different pasts and other elements of Russian national tradition into 
a single contemporary national narrative" (cf. Malykhina 2014: 181; Tolz /forthcoming/).

The created ambiguity of a viewpoint arrangement of "Infectious" is reinforced through the usage of its central metaphor IDEAS ARE INFECTION. As shown above this metaphor is activated through the Onishchenko's announcement related to a real life swine flu epidemic. Although backgrounded in the first half of the story, the Reader's knowledge of the swine flu epidemic still remains activated through the imagined Speaker's subsequent references to Onishchenko and illnesses. The metaphor of IDEAS ARE INFECTION is conventional and already embedded in people's minds, hence on the surface, there seems to be no need to continue supporting it through such references. A closer look reveals that by continuing with the use of references to Onishchenko (Онищенко) and making references to swine flu (свиной грипn), and other bad diseases - чума (plague), холера (cholera), СПИД (AIDS) originating from the 'Other' countries, "Infectious" ensures that the metaphoric construal of ideas as infection is kept live and further negotiable. In the second half of the story, this discourse metaphor (on discourse metaphors see e.g., Zinken et al. 2007) is further extended by its reversed conceptual usage through the reference to 'Russian harmful virus and epidemia'. Consider.

Разве мы кому заносили вредный вирус с родного дна? Разве выползла из России эпидемия хоть одна? Have we ever given anyone a harmful virus from our native soil? Has even one epidemic ever crept out of Russia?

These lines activate a mental space for 'Russian communist ideas as infection', which clashes with the 'Western democratic ideas as infection' metaphoric space core to the story. The construction is ironic. It seems that the irony's intended message here is to remind the Reader of the Selves' communist past and the past SELF-OTHER ideological opposition, while once again mocking the 'demonisation of Others' strategy of the contemporary Kremlin's discourse and the Selves' (Russians) short and selective memory approach in perception of the Kremlin discourse's messages. However, these 
lines also evoke the possibility for conceptualisation of any ideas as infection, thereby adding a new important dimension to the metaphor "Infectious" is built upon. The activation of this dimension helps to shift the Selves' attention from the democratic ideas to some other categories of ideas, while resonating with the Kremlin discourse's message of 'the West is not that innocent either' and the Western policy of double standards the Kremlin routinely highlights. Consider.

Озаботься, образованеи, напряги остаток ума: грипп - "испанка". СПИД "африканей". Из Китая пришла чума. Несмотря на посул гарантский, неуемен вражеский зуд - к нам завозят синдром голландский и стокгольмский синдром везут... Хоть пешком обойди планету - всюду сопли и кровь рекой, а в России болезней нету, это климат у нас такой. Consider this, oh educated one, strain the remainder of your mind: the flu - is a Spanish lady. AIDS is an African. The Black Death came from China. In spite of the promise with guarantees, the enemy's itch has not been calmed [is unstoppable] - they are bringing in Dutch syndrome and Stockholm syndrome... You could walk the whole world on foot even - there is snot and rivers of blood everywhere, but in Russia there are no diseases, it's the climate we have, you see.

Again these lines mock the imagined Speaker's oversimplified presentation of Russia as unproblematic, but at the same time they indirectly remind the Reader of the dangers related to the idealistic perception of the OTHER Space as homogeneous and free of any problems. Overall the story's 'healthy vs ill' mental representation contributes to the creation of a multidimensional and rather ambiguous perception of the SELF Space in its relation to OTHER.

\subsubsection{Viewpoint blend (5): the presupposed answers}

Hutcheon notes that "parody always implicitly reinforces even as it ironically debunks"; she also stresses that parody can demonstrate "a very wide variety of tones and moods - from respectful to playful to scathingly critical" [...] and "its ironies can so obviously cut both ways" (Hutcheon 2000: xii). The viewpoint blending analysis of 
"Infectious" shows that it is anchored in a number of unstable ironies, which "set up zoom-out configurations in which the potential views of viewpoints threaten to proliferate uncontrollably" (Tobin \& Israel 2012: 40). These unstable ironies are either gradually get "stabilised" or on the contrary gradually add ambiguity at the discourse level of the story as a whole. Working together deictic, metaphoric, intertextual, poetic, ironic construals (among others), constrain the proliferation of views of viewpoints behind local unstable ironies, narrowing them down from total 'uncontrollable' (Tobin $\&$ Israel 2012) to those that would give more authority to the arguments of the parody or the arguments of the target of parody. Tobin and Israel argue that central to the process of successful irony interpretation is the reconstruction of the viewpoint blend in such a way that it resolves any inconsistencies (Tobin \& Israel 2012: 32). It seems that for "Infectious" such irony's resolutions manifest themselves in providing the parodic blending network with a range of tones and moods (to repeat Hutcheon's words), wide and creative enough for the Reader to formulate the presupposed answers. It seems that the story's 'answers' can be conceptualised as framing and mocking the Selves' (Russian people's) denial to recognise the Kremlin discourse's strategy of the Others' demonization, and the resulting formation of national unity as an attempt to shift the Selves' attention from the Russian internal issues to the formation external "enemy" (OTHER). "Infectious" appreciates the nature of such a denial through framing the alternative scenario of the Selves' taking responsibility for the Russian internal issues as a rather complex and painful process, linguistically triggered by the story's expository questions Где мы нынче? Делаем что мы? Как мы прожили двадиать лет?! Where are we now? What are we doing? How have we lived for twenty years?! The presupposed answers to these questions constitute the emergent structure of Viewpoint Blend (5), produced by further mapping of the deictic, metaphoric, ironic, intertextual, 'question' construals discussed above (among others) with the poetic and polyphonic blends of "Infectious". 
Sweetser (2006) argues that rhyme and meter play a huge role in the literary interpretation of the text and in our understanding of irony and intertextuality. Following Sweetser (2006) I view the metrical line units, rhymes, line-internal rhymes, and formal grouping of lines as meaning units. For example, the polyphonic blend constructed behind the clause Прав Онищенко (Onishchenko is right) reinforces the idea of the Selves' shared responsibility for Russia being ill, simultaneously foregrounding the nostalgia for great healthy powerful Russia with its 'imperial pride'. With two unstressed 'o', прав Онищенко can be read as 'праванищенка' or 'права нищенка' (the beggarwoman is right, of feminine gender in Russian), where the negatively evaluated 'beggarwoman' can metaphorically represent post-Soviet Russia: the Empire on its knees (contemporary SELF), always right, but currently poor in many different respects (on the dominance of imperialism in Russia see e.g. Rowley 2000). Although primarily focusing on and evaluating the SELF Space, "Infectious" cannot escape dealing with the question of SELF-OTHER (Свой-Чужой) opposition, central to the cultural frame deeply embedded in Russian people minds (Stepanov 2004). "Infectious" offers the presupposed answer in hinting at breaking this binary opposition. Recall the opening and concluding lines of "Infectious":

Внешний мир на бескрайнем блюде разложил свои города. Прав Онищенко across the endless plate [earth]. Onishenko is right-our people must not move there.

Due to having its two interlinked meanings, мир simultaneously prompts the activation of the 'world' and 'peace' concepts; на бескрайнем блюде (endless plate) evokes the concept of 'воля' (space and freedom); свои (self) carries a positive connotation by default. The lines prompt the conceptualisation of the OTHER Space with its own cities as positive, peaceful, large and free, which clashes with the more superficial ironic (negative) interpretation of the OTHER in the same lines. The lines trigger the construction of the highly creative rhyme/meter blend, integrating the OTHER and SELF Spaces: свои города - уезжать туда (own cities - move there), meaning 'when people travel/move abroad, they travel/move to their own cities (the SELF Space), 
thereby getting rid of the binary opposition SELF-OTHER. Furthermore, the rhyme blends на бескрайнем блюде with наши люди (the endless plate - our people), prompting the emergence of the construction of the new category of the post-Soviet Russian people, existing and acting in the space without borders - whose freedom is not restricted by any authorities, people of the world.

However, the original Russian 'default' cultural frame of 'Self-Other', exploited by the contemporary Kremlin-sponsored discourse, and enhancing and successfully imposing the concepts of patriotism, imperialism and nationalism, is too strong to allow the complete shift to and acceptance of the new emergent solution-answer of breaking the 'Self-Other' binary opposition in the Reader's mind. The construction of the viewpoint blending network behind "Infectious" is further constrained by the governing principles (Fauconnier \& Turner 2002). Following Freeman (2005), I view governing (optimality) principles as the conceptual tools (construal operations) the poet works with to construct the poem, and the reader - to construe it. The clash between two ways of framing the SELF-OTHER relation, namely: 'breaking' vs 'maintaining' the binary opposition, leads to violation of Topology, Integration and Web principles and subsequently to the emergence of the meta-parodic relation in the viewpoint blending network of "Infectious". To afford meta-parody, Integration of two viewpoint blends - input mental spaces (parodic and parodized) has to be relaxed and the respective two sets of topologies have to be maximised and intensified in turn, depending on the Reader's possible evaluations in the process of "Infectious" interpretation. As distinct to the blending network model of irony offered in Tobin \& Israel (2012), the parodic viewpoint blend does not seem to fully embrace the parodised viewpoint in the metaparodic network of "Infectious" in a sense that it does not offer the interpretation of the 'parodic' viewpoint as superior to the 'parodised' viewpoint. The duality of the metaparodic relation in the Viewpoint Blend (5) pushes in a direction of maximising and intensifying Topology, resulting in the former violating Web. Hence, the maintaining of the web (of appropriate connections) in the viewpoint network becomes more 
difficult. As a result, the Reader constructs the less optimal but more elaborated complex meta-parodic blend of Infectious where two ways of reasoning simultaneously conflict and integrate, thereby producing mixed interpretations and emotions (see Figure 2 representing the viewpoint blending network of Infectious).

Figure 2 illustrates the relation between the Grounding Space (incorporating the Ground) with the Content Space and the three key Viewpoint Spaces, constructed through the cascades of viewpoint 'Self WE (1-4)' blends and 'Selves jointly attending to SELF (1-5)' blends, as analysed above. Parodic Viewpoint Space functions as a blend, representing the Viewpoint of the (parodized) Viewpoint. The attention zooms out of the Parodised to the Parodic space, however, the Reader's denial leads to the outer-space mappings between Parodised Viewpoint and Parodic Viewpoint spaces not resulting in the Parodic Viewpoint Space (Parodic Viewpoint Blend') full embracement of the Parodised Viewpoint. Ultimately, both spaces function as input mental spaces for constructing the Meta-parodic Viewpoint Blend". In the Meta-parodic Viewpoint Blend" there is a dynamic inner-space relation between parodised and parodic SELFOTHER framings relying on the network's compression/decompression operations. Meta-parodic Viewpoint Blend" involves Blended Selves jointly attending to the Selves" (Russians) as part of the SELF" Space (Russia). In the blend's (Meta-parodic Viewpoint Blend " emergent structure, the SELF" Space embraces the Other Space. This emergent structure is unstable; the resulting evaluations and emotions are mixed. Metaparodic interpretation of "Infectious" relies on the running of the underlying viewpoint blending network as a whole. 


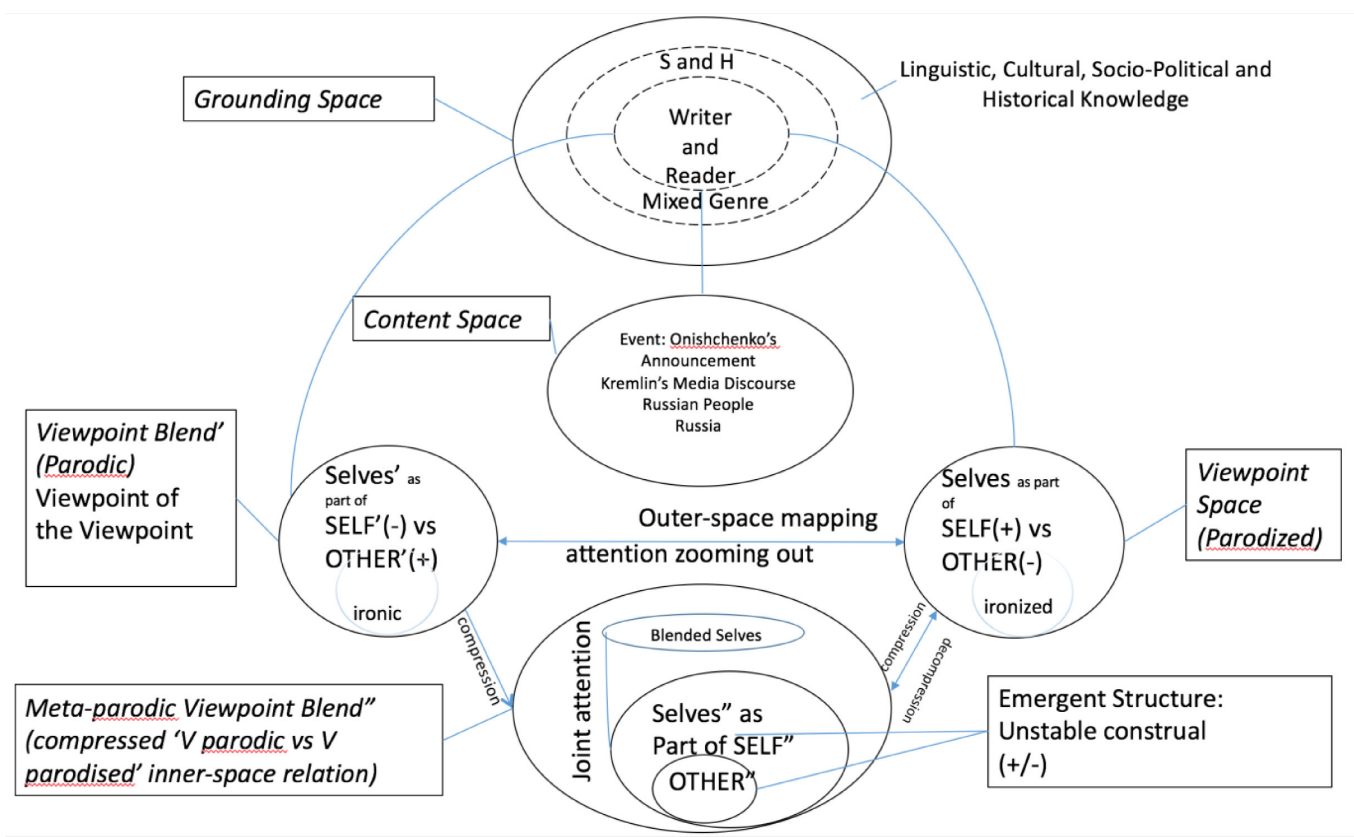

Figure 2. Viewpoint Blending Network of Infectious

Morson's notion of meta-parody (1989) resonates with the Hutcheon's notion of postmodern parody. Hutcheon argues that in contrast to parody, "not only is there no resolution (false or otherwise) of contradictory forms in postmodern parody but there is a foregrounding of those very contradictions" (Hutcheon, 2002: 90). She points out that "it is the complicity of postmodern parody - its inscribing as well as undermining of that which it parodies - that is central to its ability to be understood" (Hutcheon, 2002: 101). The complex and ambiguous meta-parodic (postmodern parodic) message of "Infectious" can be seen as summarised by the title of the poem. It seems that it is not by accident that Bykov chooses the adjective Заразное (Infectious) as opposed to the noun 'зараза' (infection), and not just an adjective but its neuter form. This way 'Заразное' can be read as 'За разное', with the most creative polyphonic blend underlying the phrase, meaning 'I am for the difference/variety', and by extension - I am for the variety of viewpoints, voices and arguments?

\section{Discussion and conclusion}

Using linguistic viewpoint (grounded in mental spaces theory), conceptual blending and blended joint attention as the core methods of analysis, I have demonstrated in some 
detail how various Russian linguistic, prosodic and visual clues of "Infectious" trigger the construction of interrelated and interdependent viewpoint blends. The study has shown that a wide range of linguistic clues, as well as prosodic and visual triggers, at all discourse levels from phonemes to discourse as a whole, work to produce deictic, multimodal, ironic, 'expository question', metaphoric, metonymic, counterfactual, intertextual, poetic, polyphonic, parodic and metaparodic blends behind "Infectious". The ability of these blending construals to work together (cf. Kovecses 2015: 29) is central to the construction and successful running of the viewpoint blending network of Infectious and the emergence of the network's meta-parodic meaning. The construals' work jointly to construct the blended Selves (WE) and their blended joint attention to a number of discourse Objects. The network's compression and decompression operations construct the parodised and parodic viewpoint spaces and ultimately help to maintain the meta-parodic relationship between them. The Selves' blended joint attention gradually zooms out from the more basic and unstable ironic viewpoint spaces to more elaborate and sophisticated meta-parodic space for SELF and Selves (Russia and Russians), in the process of the Reader's search for answers and solutions to the questions and incongruities posed by "Infectious". The resulting meta-parodic blending network supports the story's intended message, or in other words, the dynamic viewpoint configuration where "one side of the dialogue [...] may seem to be predominant, but that predominance is inconclusive and never free from the possibility of reversal" (Morson 1989: 85). The weighting of parodic and parodised viewpoints at a given moment in time is supported and constrained by the scene of blended joint attention (the ground) and the broader grounding space (the context), which "is never predetermined and objectively existing; it must be created (and recreated) in the course of the communicative process" (Kovescses 2015: x-xi). The reader's perception of the parodic and parodised viewpoints and the inter-relation between them, triggered by "Infectious", is grounded in the reader's knowledge and understanding of the contemporary Russian context, which in its turn is conditioned by Russian culture, history, socio-political situation, the influence of media discourse as a whole, etc. Naturally, the linguistic and visual clues of "Infectious" trigger 
the emergence of meanings and messages in the minds of the Russian readers living in Russia, which would be different from meanings and messages, constructed in the minds of the readers living outside Russia.

Freeman (2005) argues that the analysis of the poem as a complex blend allows for the revelation of some of the poet's thoughts and attitudes in the process of composition, and helps to understand how the reader is likely to interpret the poem. I argue that combining blended joint attention with linguistic viewpoint and conceptual blending approaches affords the finer grained account of linguistic (and multimodal) viewpoint arrangement underlying the mixed genre event of Infectious. The analytical approach developed by my study of "Infectious" allows investigating the complex configuration of multiple participants (including the imagined Speaker and the Hearer, implied Author and the implied Reader) and their multiple and shifting viewpoints, simultaneously conveying such attitudes as irony, distance, denial, acceptance, etc.

The study's viewpoint blending analysis reveals that the intended message of "Infectious" is multi-layered and complex. Although criticising the current state of affairs in Russia, "Infectious" foregrounds the Russian people as jointly responsible for the problems experiencing by Russia. "Infectious" works to highlight the Russian issues through ironic construals, at the same time demonstrating that every SELF conceptualisation and evaluation is contradictory and the related emotions are mixed. The story criticises and indirectly supports the 'othering', simultaneously; as it does for other important strands of the discourse related to the Kremlin-sponsored nationbuilding project. "Infectious" rather reflects the contradictions of the dominant [Kremlin nation-building] discourses that in their turn "correlate with the contradictory definitions of Russianness in public opinion" (cf. Chaisty \& Whitefield 2016; Tolz /forthcoming/: 31). The story's intended message promoting the breaking of the binary opposition 'SELF-OTHER' can be seen as an attempt to re-conceptualise or interpret the 'sovereign democracy' ideology central to Kremlin's discourse, which according to Tolz 
(forthcoming: 31) "materialises in the co-existence of wide-spread public support for Russia's special path of development with a simultaneous belief that governmental policies should be based on universal democratic values".

"Infectious" is representative of Bykov's journalistic and literary activity, both in terms of general parodic content and poetic form. As Polonsky notes: "Hardly a day passes without at least one article, broadcast, or blog in which Bykov finds some ingenious connection between a political event and a line of poetry [...] (Polonsky 2012: 58). Furthermore, the study's viewpoint blending analysis has shown that "Infectious" is representative of the contemporary Russian literature, culture and thought, as striving "to define what is Russian, in both individual and national terms, whilst also exploring what is human" (Marsch 2007: 531). Marsch points out to "the resurgence of traditional notions of Russia's uniqueness" and "a heightened awareness of the presence (often the malign influence) of 'the Other', in the contemporary Russian literature. She notes that "contemporary Russian culture suggests that conventional views of a homogenised West as Russia's 'Other' are by no means outdated - indeed they are becoming more prevalent in the twenty-first century"; while underscoring that in contemporary Russian literature and film, "attitudes to the West remain as varied and as ambivalent as they have always been (Marsch 2007: 531). The contemporary Russian literary and cultural space is further characterised as by self-censorship, commercialisation of Russian cultural production and attempts to revive Russian cultural imperial hegemony and promote Russia's role in the Eurasian space in a reinvented messianic manner, among others (cf. Lyutskanov et al. 2014; Smith /forthcoming/). Traditionally Russian poets are perceived as ascribed with the civic duty and the messianic role. By evoking the cultural network of civic poetry in "Infectious", Bykov puts himself in one line with Russian civic poets, which can be seen as developing his self-representation as an upholder of Russian civic poetry tradition (cf. Lyutskanov et al. 2014; Smith /forthcoming/). 
Highlighting the specifics of post-Soviet subjectivity and foregrounding the contradictions, "Infectious" realises the post-modern condition (cf. Hutcheon 2002; Smith forthcoming). It does so through the meta-parodic less optimal and more elaborate blending of the contrasting and shifting viewpoints in a mixed genre event of "Infectious", thereby motivating the Reader's interpretation of the story as ambiguous, often linked to the Reader's negative evaluations. According to Gavin (2013) the mixed genre on its own can be a reason of Reader's conflicted and negative story's perception. In her cognitive poetic analysis of absurd, Gavins underscores that "readers' interactions with all literary texts are highly context-dependent and their evaluations of their individual reading experiences are based very much on pre-existing schematic understanding of a given genre". Having analysed the readers' responses, Gavin notes that literary works prototypical for their genres are generally rated most highly compared to literary works of mixed genres, which are often assessed negatively by readers as causing irritation and disappointment; in so doing the readers seem to reject the role of implied reader they believe the literary work is constructing (Gavins 2013:123-125). Emotion has been investigated by media psychology scholars as a key construct in media messages processing (Konijn \& ten Holt 2011). I argue that conflicted and negative evaluations of "Infectious" by the readers as well as the respective emotions (which I referred to in Section 3.1.2) constitute the integral part of the underlying viewpoint blending network, contributing to the story's interpretation as meta-parodic, as opposed to parodic.

The study's analysis of "Infectious" has demonstrated that combining linguistic (multimodal) viewpoint, conceptual blending and blended joint attention in one analytical model satisfies the need for a cognitive based model for the analysis of complex multiple viewpoints and the related linguistic (visual and prosodic) markers found at various discourse levels (Dancygier 2012; Sweetser 2012), as well as for the cognition-based model for genre analysis (Steen 2011). As shown by this study, such an analytical model can be successfully applied for the examination of the typology of 
linguistic and multimodal markers triggering viewpoint blends, specific to a certain genre. Furthermore, the study's analysis adds to the understanding of irony (Tobin \& Israel 2012) and parody (Morson 1989; Hutcheon 2000 and 2002) in their interrelation. The study elucidates the role of mixed genre structures, cultural, socio-political and historical frames, among other contextual factors, in viewpoint construction behind these genres. Ultimately, the viewpoint blending analysis of "Infectious" reveals important aspects of the national identity formation in contemporary Russia.

The study has only touched upon the subject of interdisciplinary investigation of metaparody; more work has to be done. I am currently engaged in the further testing of the model, as applied to the exploration of the meta-parodic viewpoint construction in Bykov's major project "Citizen-Poet", for which, I argue, the analysis of "Infectious" has provided a good foundation.

\section{References}

Anderson, B. (2006). Imagined communities: reflections on the origin and spread of nationalism (New Edition). London-New York: Verso Books.

Bacon, E. (2014). Contemporary Russia (revised and updated 3rd edition). Basingstoke: Palgrave Macmillan.

Barkovskaya, N. (2014). Poet and Citizen: canon game in contemporary Russian poetry. In Russian classical literature today: The challenges/trials of messianism and mass culture. Lyutskanov, Y., Manolakev, H. \& Ruse, R. (eds.). Cambridge: Cambridge Scholars Publishing, p. 110-125.

Blended classic joint attention. Available at: http://www.redhenlab.org/home/the$\underline{\text { cognitive-core-research-topics-in-red-hen/the-barnyard/blended-classic-joint- }}$

\section{$\underline{\text { attention }}$}

Brandt, L. (2013). The communicative mind: A linguistic exploration of conceptual integration and meaning construction. S.l.: Cambridge Scholars Publishing. 
Burgers C., van Mulken, M. \& Schellens, P.J. (2013). On verbal irony, images and creativity: A corpus-analytical approach. In Creativity and the agile mind: a multidisciplinary approach to a multifaceted phenomenon (Applications of cognitive linguistics, 21). Feyaerts, K., Veale T. \& Forceville C. (eds.). Berlin-New York: Mouton de Gruyter, p. 293-310.

Cap, P. (2014). Expanding CDS methodology by cognitive-pragmatic tools: proximization theory and public space discourses. In Contemporary studies in critical discourse analysis. Hart, C. \& Cap, P. (eds.). London: Bloomsbury, p. 189-210.

Cavanagh, C. (2010). Lyric poetry and modern politics: Russia, Poland, and the West. New Haven and London: Yale University Press.

Chaisty, P. \& Whitefield, S. Dimensions of nationalism in Putin's Russia and their political correlates. Paper presented at the workshop on "Citizen Preferences, Political Mobilization, Institutional Change, and Regime Stability in Russia and Ukraine". London School of Economics, 10 June 2016. The abstract is available at http:/popularmobilization.net/wp-content/uploads/2016/02/Workshop-ScheduleJune-2016.pdf

Cherkasova, M.N. / Черкасова М.Н. (2011). К вопросу о фреймово-слотовой структуре концепта Дурак. In Вопросы когнитивной лингвистики, 4 (029) 2011, p. 74-82. Available at: http://cyberleninka.ru/article/n/k-voprosu-o-freymo-slotovoystrukture-kontsepta-durak.pdf

Chilton, P. (2005). Manipulation, memes and metaphors: the case of Mein Kampf. In Manipulation and ideologies in the twentieth century: discourse, language, mind. de Saussure L. \& Schulz, P. (eds.). Amsterdam/Philadelphia: John Benjamins Publishing Company, p. 15-43.

Chilton, P. (2008). Reflections on blends and discourse. In Mental spaces in discourse and interaction. Hougaard A. \& Oakley, T. (eds.). Amsterdam-Philadelphia: John Benjamins Publishing Company, p. 251-257.

Chilton, P. (2014). Language, space and mind: the conceptual geometry of linguistic meaning. Cambridge: Cambridge University Press. 
Dancygier, B. (2006). Preface: What can blending do for you? In Language and literature, 15 (1): A special issue on 'blending', Dancygier, B. (ed.), p. 5-15.

Dancygier, B. (2008). The text and the story. In Mental spaces in discourse and interaction. Hougaard A. \& Oakley, T. (eds.). Amsterdam/Philadelphia: John Benjamins Publishing Company, p. 51-78.

Dancygier, B. (2012). Conclusion: multiple viewpoints, multiple spaces. In Viewpoint in language: A multimodal perspective. Dancygier, B. \& Sweetser, E. (eds.). Cambridge: Cambridge University Press, p. 219-231.

Viewpoint in language: A multimodal perspective. (2012). Dancygier, B. \& Sweetser, E. (eds.). Cambridge: Cambridge University Press.

Dirven, R., Polzenhagen, F. \& Wolf Hans-Georg. (2007). In Cognitive linguistics, ideology and critical discourse analysis. Geeraerts, D. \& Cuyckens H. (eds.) The Oxford handbook of cognitive linguistics. Oxford: Oxford University Press, p. 12221241.

Etkind, A. (2011). Internal Colonisation: Russia's Imperial Experience. Cambridge: Polity Press.

Fauconnier, G. (1985). Mental Spaces. Cambridge: Cambridge University Press.

Fauconnier, G. \& Turner, M. (2002). The way we think: conceptual blending and the mind's hidden complexities. New York: Basic Books.

Ferrari, L. \& Sweetser, E. (2012). Subjectivity and upwards projection in mental space structure. In Viewpoint in language: A multimodal perspective. Dancygier, B. \& Sweetser, E. (eds.). Cambridge: Cambridge University Press, p. 47-68.

Forceville, C. (2013). Creative visual duality in comics balloons. In Creativity and the agile mind: a multidisciplinary approach to a multifaceted phenomenon (Applications of cognitive linguistics, 21). Feyaerts, K., Veale T. \& Forceville C. (eds.). Berlin-New York: Mouton de Gruyter, p. 253-273.

Freeman, M. (2007). Cognitive linguistic approaches to literary studies: state of the art in cognitive poetics. In The Oxford Handbook of Cognitive Linguistics. Geeraerts, D. \& Cuyckens, H. (eds.). Oxford: Oxford University Press, p. 1175-1202. 
Freeman, M. (2005). The poem as complex blend: conceptual mappings of metaphor in Sylvia Plath's 'The Applicant'. In Language and literature, 14(1), p. 25-44

Fritzsche, P. (2004). Stranded in the present: modern time and the melancholy of history. Cambridge: Harvard University Press.

Gavins, J. (2013). Reading the absurd. Edinburgh: Edinburgh University Press.

Grenoble, L.A. (1998). Deixis and information packaging in Russian discourse (Pragmatics \& Beyond, 50). Amsterdam: John Benjamins Publishing Company.

Harbus, A. (2012). Cognitive approaches to Old English poetry. S.1.: D.S. Brewer.

Hart, C. (2010). Critical discourse analysis and cognitive science: new perspectives on immigration discourse. Basingstoke: Palgrave Macmillan.

Contemporary studies in critical discourse analysis. (2014). Hart, C. \& Cap. P. (eds.). London: Bloomsbury.

Mental Spaces in Discourse and Interaction. (2008). Hougaard, A., \& Oakley, T. (eds.). Amsterdam/Philadelphia: John Benjamins Publishing Company.

Hutcheon, L. (2000). A theory of parody: the teachings of twentieth-century art forms (Reprint edition). Urbana-Chicago: University of Illinois Press.

Hutcheon, L. (2002). The politics of postmodernism ( $2^{\text {nd }}$ edition). London-New York: Routledge.

Hutchings, S., \& Tolz, V. (2015). Nation, ethnicity and race on Russian television: mediating post-Soviet difference. (BASEES/Routledge Series on Russian and East European Studies). Abingdon: Routledge.

Khriptulova T.N. / Хриптулова Т.Н. (2014). "Берендеево царство" Н.И. Тряпкина. In Историческая и сочиально-образовательная мысль, 3, p. 245-247. Available at: http://www.hist-edu.ru/hist/article/view/334/330

Konijn, E.A. \& ten Holt, J.M. (2011). From noise to nucleus: emotion as key construct in processing media messages. In The Routledge Handbook of Emotions and Mass Media. Doveling, K., von Scheve, Ch. \& Konijn, E.A. (eds.). Abingdon: Routledge, p. 37-59. 
Kopytowska, M. (2013). Blogging as the mediatization of politics and a new form of social interaction: a case-study of 'proximization dynamics' in Polish and British political blogs. In Analyzing genres in political communication: theory and practice. Cap, P. \& Okulska, U. (eds.). Amsterdam: John Benjamins Publishing Company, p. $379-421$.

Kovecses, Z. (2015). Where metaphors come from? Oxford: Oxford University Press. Kuhiwczak, P. (2006). Outwitting the politburo: politics and poetry behind the Iron Curtain. In Cold War literature: writing the global conflict. Hammond A. (ed.). London-New York: Routledge, p. 195-211.

Lakoff, G. \& Turner, M. (1989). More than cool reason: A field guide to poetic metaphor. Chicago-London: The University of Chicago Press.

Lyutskanov, Y., Manolakev, H. \& Ruse, R. (2014). Introduction. In Russian classical literature today: The challenges/trials of messianism and mass culture. Lyutskanov, Y., Manolakev, H. \& Ruse, R. (eds). Newcastle upon Tyne: Cambridge Scholars Publishing, p. 1-13.

Malykhina, S. (2014). Renaissance of classical allusions in contemporary Russian media. Lanham: Lexington Books.

Marsh, R. (2007). Literature, history and identity in post-Soviet Russia, 1991-2006. Bern: Peter Lang.

Marsh, R. (2011). The "new political novel" by right-wing writers in post-Soviet Russia. In Forum für osteuropäische Ideen- und Zeitgeschichte, 14 (1), p. 159-187.

Morson, G. S. (1989). Parody, history and metaparody. In Rethinking Bakhtin: extensions and challenges. Morson G. S. \& Emerson C. (eds.). S.l.: Northwestern University Press, p. 63-86.

Nesset, T., Endresen, A., Janda, L., Makarova, A., Steen, F., \& Turner, M. (2013). How 'here' and 'now' in Russian and English establish joint attention in TV news broadcasts. In Russian Linguistics, 37(3), p. 229-251.

Nikiforidou, K. (2012). The constructional underpinnings of viewpoint blends: the Past + now in language and literature. In Viewpoint in language: A multimodal 
perspective. Dancygier, B. \& Sweetser, E. (eds.). Cambridge: Cambridge University Press, p. 177-197.

Oakley, T. \& Coulson, S. (2008). Connecting the dots: mental spaces and metaphoric language in discourse. In Mental spaces in discourse and interaction. Hougaard A. \& Oakley, T. (eds.). Amsterdam/Philadelphia: John Benjamins Publishing Company, p. 27-51.

Oakley, T. \& Kaufer, D. (2008). Designing clinical experiences with words: Three layers of analysis in clinical case studies. In Mental spaces in discourse and interaction. Hougaard A. \& Oakley, T. (eds.). Amsterdam/Philadelphia: John Benjamins Publishing Company, p. 149-179.

Oushakine, S. (2007). "We're nostalgic but we're not crazy": retrofitting the past in Russia. In Russian Review, 66 (3), p. 451-482.

Paducheva, E.V. / Падучева Е.В. (2004). Динамические модели в семантике лексики. Москва: Языки славянской культуры.

Paducheva, E.V. (2011). The linguistics of narrative. The case of Russian. S.1.: Lambert Academic Publishing.

Paducheva, E.V. / Падучева Е.В. (2012). Неопределенно-личное предложение и его подразумеваемый субъект. In Вопросы языкознания, 1, p. 27-41. Available at: http://lexicograph.ruslang.ru/TextPdf1/Neopr_Lichn_VYa.pdf

Pagan Canovas, C. (2011). Erotic emissions in Greek poetry: A generic integration network. In Cognitive semiotics, 6, p. 7-32.

Panov, P. (2010). Nation-building in post-Soviet Russia: What kind of nationalism is produced by the Kremlin? In Journal of Eurasian Studies, 1(2), p. 85-94.

Pascual, E. (2014). Fictive interaction: the conversation frame in thought, language, and discourse. Amsterdam-Philadelphia: John Benjamins Publishing Company.

Pleshakova A. (2010). Werewolves in Epaullettes. In Meaning, form, and body. Parrill, F., Tobin, V., \& Turner, M. (eds.). Stanford: CSLI Publications, p. 263-286.

Pleshakova, A. (2014). Strike, accident, risk, and counterfactuality: hidden meanings of the post-Soviet Russian news discourse of the nineties via conceptual blending. In 
Language and cognition: An interdisciplinary journal of language and cognitive science, 6(3), p. 301-306.

Pleshakova, A. Cognitive approaches to media and language. In The Routledge handbook on language and media. Cotter C. \& Perrin, D. (eds.). S.l.: Routledge. (forthcoming).

Polonsky, R. (2012). 8 November. "Russia: The Citizen Poet". The New York Review of Books, Available at: http://www.nybooks.com/articles/2012/11/08/russia-citizenpoet/

Read Russia 2013. Available at: http://readrussia2013.com

Rogachevskii, A. (2006). The Cold War representation of the West in Russian literature. In Cold War literature: writing the global conflict. Hammond A. (ed.). London-New York: Routledge, p. 31-45.

Rowley, D. (2000). Imperial versus national discourse: the case of Russia. In Nations and Nationalism, 6 (1), p. 23-42.

Sambre, P. (2013). Multimodal blending and musical creativity: dualities in the quixotry of Richard Strauss, Jan Sandström and Christian Lindberg. In Creativity and the agile mind: a multidisciplinary approach to a multifaceted phenomenon (Applications of cognitive linguistics, 21). Feyaerts, K., Veale T. \& Forceville C. (eds.). Berlin-New York: Mouton de Gruyter, p. 315-333.

Sanders, R., Wu, Y. \& Bonito, J.A. (2013). The calculability of communicative intentions through pragmatic reasoning. In Pragmatics \& Cognition, 21(1), p. 1-34.

Savitskaya, L.V. / Савицкая Л. В. (2013). Языковая репрезентация концепта "хитрость" в славянских сказках. In Русская филология, 1-2, p. 39-46.

Semino, E. (2006). Blending and characters' mental functioning in Virginia Woolf's Lappin and Lapinova. In Language and literature, 15(1), p. 55-73.

Sinding, M. (2005). "Genera Mixta": conceptual blending and mixed genres in "Ulysses". In New literary history, 36 (4), an issue on exploring language in philosophy, poetry, and history, p. 589-619. 
Sinding, M. (2010). Framing monsters: multiple and mixed genres, cognitive category theory, and Gravity's Rainbow. In Poetics today, 31(3), p. 465-505.

Sinjavskij, A.D. / Синявский А.Д. (2001). Иван-дурак: Очерк русской народной веры. Москва: Аграф.

Smith, A. The post-Soviet homecoming of first-wave Russian Émigré poets and its impact on the reinvention of the past". In Twentieth-century Russian poetry: reinventing the canon. Hodgson, K., Shelton, J. \& Smith A. (eds.). Cambridge: Open Book Publishers. Forthcoming.

Steen, G. (2011). Genre between the humanities and sciences. In Bi-Directionality in the cognitive sciences. Callies, M., Keller, W.R. \& Lohofer, A. (eds.). Amsterdam: John Benjamins Publishing Company, p. 21-42.

Stepanov, Yu. / Степанов Ю.С. (2004). Константы: Словарь русской культуры. Москва: Академический проект.

Stockwell, P. (2007). Cognitive poetics and literary theory. In Journal of literary theory, 1(1), p. 135-152.

Sweetser, E. (2006). Whose rhyme is whose reason? Sound and sense in Cyrano de Bergerac. In Language and literature, 15(1) p. 29-54.

Sweetser, E. (2012). Introduction: viewpoint and perspective in language and gesture, from the Ground down. In Viewpoint in language: A multimodal perspective. Dancygier, B. \& Sweetser, E. (eds.). Cambridge: Cambridge University Press, p. 1-24. Tobin, V. \& Israel, M. 2012. Irony as a viewpoint phenomenon. In Viewpoint in language: A multimodal perspective. Dancygier, B. \& Sweetser, E. (eds.). Cambridge: Cambridge University Press, p. 25-46.

Tolz, V. Russia: exiled, submerged, restored. In The Oxford handbook of modern Russian history. Dixon, S. (ed.). Oxford: Oxford University Press. Forthcoming. Turner, M. (2014). The origin of ideas: blending, creativity, and the human spark. Oxford: Oxford University Press.

Verhagen, A. (2005). Constructions of intersubjectivity: discourse, syntax, and cognition. Oxford: Oxford University Press. 
Xiang, M. \& Pascual, E. (2016). Debate with Zhuangzi: expository questions as fictive interaction blends in ancient Chinese philosophy. In Pragmatics, 26(1), p. 137-162. Zinken, J., Helsten, I. \& Nerlich, B. (2007). Discourse metaphors. In Body, Language and Mind: Sociocultural Situatedness. Frank, R., Dirven, R., Ziemke, T. \& Bernardez, E. (eds.). Berlin-New York: Mouton de Gruyter, p. 363-387.

Znamenskaya, O.Е. / Знаменская О.Е. (1985). Семантико-функциональная характеристика частицы ВЕДЬ в современном русском литературном языке / Дис. ... канд. филол. наук / 10.02.01 - русский язык, Москва. Available at: http://www.dissercat.com/content/semantiko-funktsionalnaya-kharakteristikachastitsy-ved-v-sovremennom-russkom-literaturnom-y\#ixzz4HINh19mi

\section{Appendix 1}

Заразное

Внешний мир на бескрайнем блюде разложил свои города. Прав Онищенко - наши люди не должны уезжать туда.

Я не три, не четыре раза ездил в ихние города, и о том, что у них зараза, я догадывался всегда. Возвращаясь в край колоколен, где двуглаво рулит тандем, я догадывался, что болен, - не вполне понимая, чем. Знать, покуда по Пикадилли беззаботно гулялось мне - заразили, мля, наградили. Влили в чай, поднесли в вине. А потом прилетишь обратно, влезешь в шлепанцы, снимешь фрак - все не так, а что непонятно. Все как было - и все не так. Из-за моря вернулась птаха, и в ушах у неё свистит: меньше гордости, больше страха, иногда беспричинный стыд... Вдруг

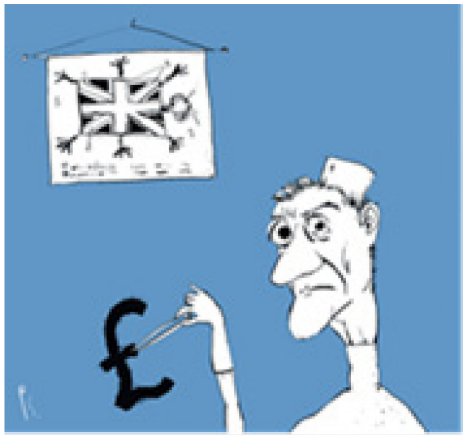
кольнёт незримое жало, как отравленная игла: хорошо бы власть уважала, а милиция - берегла... Где мы нынче? Делаем что мы? Как мы прожили двадцать лет?! Разумеется, все симптомы за неделю сходят на нет, потому что в России лето, машет сиськами молодежь, а родного иммунитета, слава Богу, не 
прошибешь. Начинаешь ходить, не горбясь, уважать не талант, а чин, обретаешь былую гордость, не ища для нее причин, ловишь кайф от родных идиллий, вечерами включив ТВ, и не помнишь про Пикадилли, где микроб занесли тебе. Не впервой под британским флагом воровские творить дела: ты-то все объяснял джет-лагом, а ведь это болезнь была! Ты купился, как лох, на "велкам", в заповедник зараз полез - возомнил себя человеком, а ведь это болезнь, болезнь.

Обещаем не ради фразы - не водиться, не брать взаймы, потому что они заразы, лютый яд для таких, как мы. Внешний мир угрожает гробом, повернёмся к нему спиной: в этом мире лафа микробам, СПИД, холера и грипп свиной. Вы смеётесь, но этим смехом не сдержать иностранный грипп. Литвиненко туда уехал - все видали, как он погиб? Там и воля, и трали-вали, и закон справедлив и крут, - да. Но все, кто там побывали, обязательно перемрут. Лишь Онищенко бьётся, чтобы перекрыть роковой просвет: ведь у нас не живут микробы. Мы живём, а микробы - нет. Здоровее любых империй, удивительна и странна неприступная для бактерий обособленная страна. Не проскочат их вибрионы сквозь российское решето: если б твердо закрыть кордоны - не болел бы у нас никто.

Разве мы кому заносили вредный вирус с родного дна? Разве выползла из России эпидемия хоть одна? Озаботься, образованец, напряги остаток ума: грипп "испанка". СПИД - "африканец". Из Китая пришла чума. Несмотря на посул гарантский, неуемен вражеский зуд - к нам завозят синдром голландский и стокгольмский синдром везут... Хоть пешком обойди планету - всюду сопли и кровь рекой, а в России болезней нету, это климат у нас такой. Как сказал ещё Маяковский, здесь, в России, особый быт. Есть тайваньский грипп и гонконгский, а московский не может быть. Есть ходынское многолюдье и лубянский есть маховик, есть басманное правосудье, петербургский есть силовик, тульский пряник (спасибо, Тула!), газ сибирский, таманский полк, азиатская диктатура, брянский шиш и тамбовский волк, астраханский курник слоёный и рязанский кислый ранет, и архангельский гриб солёный - но российского гриппа нет. Злой 
орел или серп и молот осеняют наш гордый труд - но микробы тут жить не могут. Люди - да, а микробы - мрут.

Внешний мир на бескрайнем блюде разложил свои города. Прав Онищенко - наши люди не должны уезжать туда. Не покинем родную липу, не свернём с родной колеи, не сдадимся чужому гриппу.

Пусть нас лучше убьют свои!

\section{Loose translation (translated by the author of the article)}

Infectious

The outside world has spread its cities out across the endless earth [plate]. Onishenko is right - our people shouldn't move there.

Not three or four times have I travelled to their cities, and have always suspected that they breed a contagion. Upon returning to the land of bell towers, where the tandem steers two-headedly, I suspected that I was ill, not fully understanding what with. As I understand it now - while I was having a carefree saunter around Piccadilly, they contaminated, damn!, decorated me. They poured it into the tea, they put it in the wine. And then you arrive back home, you put your slippers on, take off your tailcoat everything is as it was, but everything is wrong. Everything is as it was, but completely different. A birdie has returned from beyond the sea, and there is whistling in her ears: less pride, more fear, sometimes an unfounded shame... Suddenly an unseen sting, like an infected needle, would prickle you - it would be good if the authorities were respectful and the police were caring... Where are we now? What are we doing? How have we lived for twenty years? Naturally, all symptoms pass within a week, because its summertime in Russia, young people are walking around flashing their tits, and your native immunity, thank goodness, will help you not to batter down. You begin to walk tall, to respect not talent, but rank, you get back your pride without looking for reasons for it, you get off on native idylls, turning on TV in the evenings, and you don't remember 
Piccadilly, where they gave you the microbe. Not for the first time under the British flag have thievish goings on taken place: you yourself put it all down to jet-lag, but you really had this illness you see! You went for it, like an idiot, the "welcome", you went into the nature reserve for infections, you believed yourself a human being, but this was a disease, a disease.

We promise not for the sake of the phrase - not to befriend, not to borrow money, because they are infection, a cruel, powerful poison for people such as us. The outside world threatens us with death, we turn our back to it: in this world so good for microbes, AIDS, cholera and swine flu. You are laughing, but you won't stop foreign flu with laughter. Litvinenko went there - did everyone see how he died? There's freedom there, you know what I mean, and justice, strict law - yes. But everyone who has been there will definitely die. Only Onishenko is striving to close off this fatal gap [chink of light]: you see, there aren't any microbes among us. We live whilst microbes don't. Healthier than any other empire, extraordinary and peculiar, inaccessible for bacteria, this country is isolated from all others. Their vibrio will not slip through the Russian sieve: and if only the cordons were firmly closed, no-one would be ill among us.

Have we ever given anyone a harmful virus from our native soil? Has even one epidemic ever crept out of Russia? Consider this, oh educated one, strain the remainder of your mind: the flu - is a Spanish lady. AIDS is an African. The Black Death came from China. In spite of the promise with guarantees, the enemy's itch has not been calmed/is unstoppable - they are bringing in Dutch syndrome and Stockholm syndrome... You could walk the whole world on foot even - there is snot and rivers of blood everywhere, but in Russia there are no diseases, it's the climate we have, you see. As Mayakovskij said in the past: here in Russia there's a special way of life. There is Thai flu and Hong Kong flu, but a Moscow flu just cannot be. There is the Xodynskij mass of people and there's the Lubyanskij flywheel, there is the Basmannovij court, and the Peterburgskij silovik, Tula gingerbread (Thanks, Tula!), Siberian gas, the Tamanskij regiment, Asiatic 
dictatorship, the Bryanskij Shish and the Tambovskij wolf, the layered Astraxanskij kurnik, the Ryazanskij sour Pippin (apple), and the salted mushroom of Arkhangelsk, but there is no such thing as Russian flu. The fierce eagle or hammer and sickle bless our proud labour - but microbes cannot live here. People survive, but microbes perish. The outside world has spread its cities out across the endless earth. Onishenko is right our people shouldn't move there. We won't leave our native lime tree, we won't turn off our native track, we won't give in to the foreign flu.

\title{
Would rather our own kind kill us instead!
}

\section{Note}

\begin{abstract}
' Bykov belongs to the group of contemporary Russian authors, whose work explores themes and values relevant to both Russia and the West, and who are becoming increasingly familiar to the Western reading audience (see e.g. the project 'Read Russia 2013' (http://readrussia2013.com) and the documentary "Russia's Open Book"). Edwin Bacon (2014) in his book "Contemporary Russia" (2014) mentions Bykov among the three 'big names' of contemporary Russian literature (p.192).
\end{abstract}

ii Novaya Gazeta (Russian: Новая газета) is a Russian newspaper well known in the country for its critical and investigative coverage of Russian political and social affairs. It is published in Moscow, regions within Russia and in some foreign countries. (Wikipedia)

iii See the 'Language and Literature' special issue on blending (2006)

iv See more on Bykov in Elena Dimov's article "Contemporary Russian Literature at UVA: Dmitrii Bykov" https://pages.shanti.virginia.edu/russian/2012/04/27/dmitrii-bykov/

v The idea of national unity often presupposes the emergence of a concept of an "enemy" within the nation-building discourse. A need for such forms has been proven to become especially crucial at times of war, economic disaster and rapid social change (Fritszche 2004), in situations very similar to that of post-Soviet Russia.

\footnotetext{
vii 'Real' hearer/reader is viewed as imagined too, as a speaker/a writer does not have a direct access to a hearer's/reader's cognitive state (see Sweetser 2012 and Turner 2014); so I use the term "real" to distinguish between two pairs - the real the author-the reader/viewer and the imagined literary speaker-hearer.

viii Наши люди (our people) triggers the construction of the blend for intertextuality, evoking the image of "ideologically correct" Soviet people with their morals, values and beliefs. The image was mocked in the infamous film "Diamond Arm" directed by Leonid Gajdaj (1968). Наши люди provides a link to the cultural frames of the Soviet reality and the Soviet travel abroad scenario, triggering the memory of the limited possibility to travel and indirectly and simultaneously activating the nostalgia for stable and powerful Soviet empire (see Oushakin 2007).
}

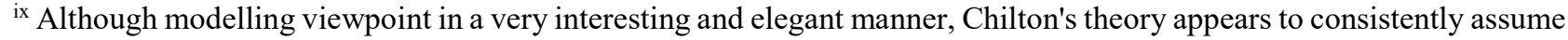
that for each Speaker, there is at any given time a single viewpoint and reference world. Since the analysis of metaparodic "Infectious" requires the examination of multiple participants and multiple shifting viewpoints in a combination of the real and imagined communicative events at a given point in time, I see blended joint attention as a framework more suitable for such an analysis.

${ }^{x}$ On the analysis of counterfactuality in Russian media texts see Pleshakova (2014)

${ }^{x i}$ On the detailed analysis of Russian discourse metaphors as blends see Pleshakova (2010). 


\begin{abstract}
xii From the research talk given by Professor Roy Allison at St Antony's College Oxford in October 2015.
xiii While referring to Alexander Blok, Sergei Esenin, Vladimir Mayakovsky and Evgeny Evtushenko, "Infectious" constructs 'intertextuality' blends, activating the whole cultural network of Russian civic poetry, which provides a further context for interpretation of the story (on allusions in Bykov's work see e.g., Malykhina, 2014 and Barkovskaya 2014).

xiv I aimed at producing a close loose translation to give some idea of the linguistic and cultural concepts involved in the story construction. I appreciate that the translation sounds rather clumsy in English and does not do a justice to Bykov's poem; however, a more sophisticated non poetic translation can only be achieved by substituting Russian metaphors with English ones, active constructions with passive constructions, etc., which would be counterproductive for presenting the cognitive linguistic (viewpoint blending) analysis of this Russian text.
\end{abstract}

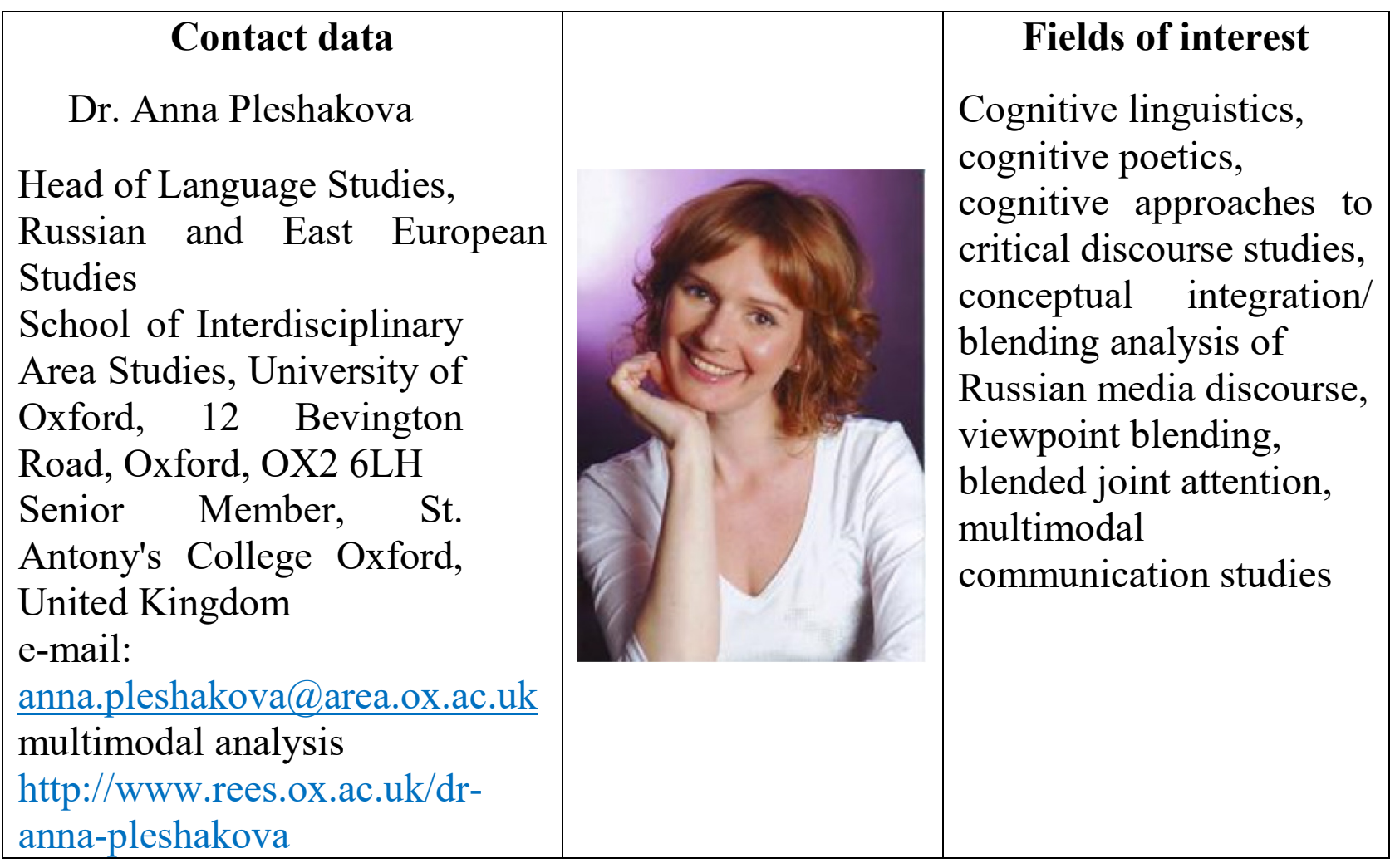

\title{
Résumé in English
}

In this paper, I use the case of Dmitry Bykov's "Заразноe" (Infectious) to explore metaparody, a genre, which has received very little attention in literary studies and has not been explored from the cognitive poetic perspective so far. I investigate Bykov's performance of meta-parody as a new Russian hybrid genre event, related to the new Russian ideology of nationalism, as well as the respective Kremlin-sponsored media discourse. I adopt Steen's (2011) logic for cognition-based interdisciplinary analysis of genre. While making use of Hutcheon's investigation of parody (2000 and 2002) 
and Morson's description of meta-parody (1989), I explore meta-parody as a viewpoint blending network, focusing on revealing and examining types of linguistic viewpoint markers and (de-) compression operations (Dancygier 2012; Sweetser 2012) that prompt the network's construction. In so doing, I utilize blended joint attention (Turner 2014), conceptual blending (Fauconnier \& Turner 2002), and viewpoint blending (Tobin \& Israel 2012; Turner 2014), as the analytical tools, to elucidate the linguistic and conceptual, as well as multimodal, situational, socio-cultural, political, literary and historical aspects behind meta-parody's production and understanding. I argue that blending analysis helps to reveal the core construal and constraint operations underlying meta-parody, and to develop an interdisciplinary cognition-based methodological model for analysis of Bykov's parodic work, as constituting part of the contemporary Russian critical media discourse.

Keywords: cognitive poetics, conceptual blending, blended joint attention, viewpoint blending, (de-) compression, genre, meta-parody, parody, irony, deixis, cultural frames, metaphor, counter-factuality, multimodality, intertextuality, poetic blends, expository questions, Russian national identity, critical discourse analysis.

\section{Résumé in German}

In diesem Aufsatz werde ich anhand von Dmitry Bykovs "Заразное" (Ansteckend) die Meta-Parodie näher betrachten, ein bis dato in der Literaturwissenschaft aus einer kognitiv-poetischen Perspektive wenig erforschtes Genre. Hierbei untersuche ich Bykovs Darstellung der Meta-Parodie als ein neues russisches Hybrid verschiedener Genres, in direktem Zusammenhang mit der aufkommenden nationalistischen Ideologie in Russland, sowie auch mit dem vom Kreml diktierten Diskurs in den Medien. Ich beziehe mich auf Steens' (2011) interdisziplinäre Analyse des Genres basierend auf erkenntnistheoretischer Logik. Durch den Bezug auf Hutcheons Untersuchung der Parodie (2000 und 2002) sowie auf Morsons Beschreibung der Meta-Parodie (1989), erforsche ich die Meta-Parodie als einen Betrachtungswinkel, der Netzwerke meliert, 
und konzentriere mich dabei auf die Offenbarung und Prüfung diverser Arten sprachlicher Betrachtungsmerkmale und (De-) Kompressierungsoperationen (Dancygier 2012; Sweetser 2012), welche zum Aufbau des Netzwerkes beitragen. Für dies bediene ich mich der vermischten Kollektivaufmerksamkeit (Turner 2014), der konzeptuellen Vermischung (Fauconnier \& Turner 2002), und der Vermischung der Perspektiven (Tobin \& Israel 2012; Turner 2014) als analytische Mittel, mit dem Ziel, sprachliche, konzeptuelle, multimodale, situationsbedingte, soziokulturelle, politische, literarische und geschichtliche Aspekte der Entstehung und des Verständisses der Meta-Parodie zu erläutern. Ich argumentiere, dass die überlappende Analyse die Kerndeutungen und restriktionen der Meta-Parodie offenbart, sowie auch zur Entwicklung eines interdisziplinären kognitiven Methodologiemodells zur Analyse von Bykovs parodischen Werkes beiträgt, als ein maßgeblicher Teil des zeitgenössischen russischen Mediendiskurses.

Stichwörter: Kognitive Poetik, Kontrafaktizität, Genre, Meta-Parodie, Deixis, Parodie, Genre, Ironie, Kulturelle Rahmen, Metapher, Multimodalität, Intertextualität, Russische Nationalidentität, Kritische Diskursanalyse, Expositorische Fragen, konzeptuelle Vermischung, (De-)Kompressierung, Vermischung der Perspektiven.

\section{Résumé in French}

Dans cet article, j'utilise le cas "Заразное" (Infectueux) de Dmitry Bykov pour explorer la méta-parodie, un genre jusque-là négligé dans les études littéraires et non encore étudié selon une poétique cognitive. Je propose d'étudier la mise en scène de la métaparodie chez Bykov comme un événement générique hybride en lien avec la nouvelle idéologie russe du nationalisme, ainsi que le discours médiatique qui en découle sponsorisé par le Kremlin. J'adopte la logique avancée par Steen (2011) pour l'analyse interdisciplinaire du genre à travers la science cognitive. Tout en m'appuyant sur les travaux de Hutcheon sur la parodie (2000 et 2002) et la description, par Morson (1989) de la méta-parodie (1989), j'envisage cette dernière comme un réseau de points de vue 
qui met en valeur et examine différents types de marqueurs linguistiques et d'opérations de (dé-) compression (Dancygier 2012; Sweetser 2012;) qui entraînent la construction du réseau. Pour se faire, j'utilise les concepts d'attention conjointe intégrée (blended joint attention, Turner 2014), d'intégration conceptuelle (conceptual blending, Fauconnier \& Turner 2002) et de mélange de points de vue (viewpoint blending, Tobin \& Israel 2012; Turner 2014) comme outils analytiques pour élucider les aspects linguistiques, conceptuels, mais aussi multimodaux, situationnels, socio-culturels, politiques, littéraires et historiques qui sont sous-jacents à notre compréhension et notre production de méta-parodie. Mon argument c'est que l'analyse d'intégration aide à mettre en valeur les constructions et contraintes des opérations de base qui sous-tendent la méta-parodie. Elle permet aussi de développer un modèle méthodologique interdisciplinaire à partir de la science cognitive pour l'analyse des travaux parodiques de Bykov et prouve que ce modèle fait partie intégrante du discours critique contemporain des médias russes.

Mots-clés: poétique cognitive, intégration conceptuelle, attention conjointe intégrée, intégration des points de vue, (dé-) compression, genre, méta-parodie, parodie, ironie, deixis, cadres culturels, métaphore, contre-factualité, multi-modalité, intertextualité, mélanges poétiques, questions d'explicitation, identité nationale russe, analyse de discours critique.

\section{Résumé in Russian}

В этой статье, на примере текста "Заразное" Дмитрия Быкова, я исследую метапародию - жанр, которому до сих пор уделялось очень мало внимания в литературоведении, и который не изучался с точки зрения когнитивной поэтики. Я анализирую использование Быковым мета-пародии как нового русского гибридного жанра, имеющего отношение к новой российской идеологии национализма, и связанного с ней медиа дискурса, спонсируемого Кремлем. Я следую логике междисциплинарного анализа жанра, основанного на когнитивном подходе, представленного в работе Steen (2011). Опираясь на исследование 
пародии в работах Hutcheon (2000 и 2002) и описание мета-пародии, данное в работе Morson (1989), я исследую мета-пародию как viewpoint blending network, фокусируясь на выявлении и изучении типов лингвистических маркеров 'вьюпойнта' (viewpoint), а также операций компрессии и декомпрессии (Dancygier 2012; Sweetser 2012), которые мотивируют построение этой сети (viewpoint blending network). Я использую теорию смешенного совместного внимания (blended joint attention; Turner 2014), концептуального блендинга (Fauconnier \& Turner 2002), и вьюпойнт блендинг (viewpoint blending; Tobin \& Israel 2012; Turner 2014) как методы анализа, для того чтобы пролить свет на такие аспекты создания и понимания мета-пародии как: лингвистический и концептуальный, мультимодальный и ситуационный, социо-политический, политический, литературный и исторический аспекты. Я утверждаю, что блендинговый анализ (blending analysis) помогает выявить основные когнитивные операции, отвечающие за построение мета-пародии, a также помогает создать междисциплинарную методологическую модель, базирующуюся на когнитивном подходе, предназначенную для анализа пародийного творчества Быкова, как части современного критического медиа дискурса.

Ключевые слова: когнитивная поэтика, концептуальный блендинг, смешанное совместное внимание, вьюпойнт блендинг, компрессия и де-компрессия, жанр, мета-пародия, пародия, ирония, дейксис, культурные фреймы, метафора, контрфактуальность, мультимодальность, интертекстуальность, поэтические бленды, 'разъяснительные' вопросы, российская национальная идентичность, критический дискурсивный анализ.

Article was received by the editorial board 19.08.16;

reviewed 3.10.16 and 30.10.16.

Similarity Index 16\%. 